\title{
İslam Hukukunda Cezalandırmada Gözetilmesi Gereken Esaslar
}

\section{Principles to be Observed in Punishment in Islamic Law}

\author{
Üveys ATEŞ \\ Dr. Öğr. Üyesi, Fatih Sultan Mehmet Vakıf Üniversitesi, Fıkıh Anabilim Dalı \\ Assist. Prof., Fatih Sultan Mehmet Vakıf University, Department of Islamic Law \\ İstanbul, Turkey \\ uates@fsm.edu.tr \\ orcid.org/0000-0002-5128-9751
}

\author{
Makale Bilgisi / Article Information \\ Makale Türü / Article Types : : Araştırma Makalesi / Research Article \\ Geliş Tarihi / Received : 14 Eylül / September 2021 \\ Kabul Tarihi / Accepted : : 26 Ekim / October 2021 \\ Yayın Tarihi / Published : 15 Aralık / December 2021 \\ Yayın Sezonu / Pub Date Season : Aralık / December \\ Cilt / Volume: 8 - Sayı / Issue: 2 - Sayfa / Pages: 411-434 \\ Atıf / Cite as \\ Ateş, Üveys. "İslam Hukukunda Cezalandırmada Gözetilmesi Gereken Esaslar". Bülent Ecevit Üniversitesi Ilahiyat \\ Fakültesi Dergisi 8/2 (2021), 411-434. \\ Doi: $10.33460 /$ beuifd.995562 \\ İntihal / Plagiarism \\ Bu makale, en az iki hakem tarafından incelendi ve intihal içermediği teyit edildi. \\ This article has been reviewed by at least two referees and scanned via a plagiarism software. \\ Yayın Hakkı / Copyright ${ }^{\circ}$ \\ CC BY-NC-ND 4.0 | Zonguldak Bülent Ecevit Üniversitesi, İlahiyat Fakültesi tarafından yayınlanmıştır. Telif ve yayın \\ hakları, Creative Commons Atıf-Gayri Ticari-Türetilemez 4.0 lisansının hüküm ve koşullarına tabidir. \\ CC BY-NC-ND 4.0 | Published by Zonguldak Bulent Ecevit University. Copyrights are subjected to the terms and conditions \\ of a Creative Commons Attribution-NonCommercial-No Derivatives License 4.0.
}

Öz: Bir toplumun huzur ve güvenliğinin temin edilmesi ve toplum fertlerinin hukukunun korunması, o toplumda adil bir cezalandırma sisteminin bulunmasına bağlıdır. Bunun için cezalandırma sisteminin bir takım ilke ve esaslara sahip olması elzemdir. Adaletin hâkim kılınmasının temel amaç olarak görüldüğü İlam hukukunda da, cezalandırma sisteminin bu amacı gerçekleştirmeye dönük esasları bulunmaktadır. Gerek naslarda ve Hz. Peygamber'in (s.a.v.) uygulamalarında gerekse islam hukukçularının ictihadlarında bu esasların izleri görülmektedir. Öte yandan suçluyu cezalandırma safhası, işlediği tespit edilen suça karşılık gelecek cezanın takdir edilmesi ve bu cezanın infaz edilmesi aşamalarını kapsamaktadır. Bu çalışmada İslam ceza hukukuna göre her iki aşamada gözetilmesi gereken ilke ve esaslar, ilgili naslardan, fıkı h kaynaklarından ve konuyla alakalı çağdaş dönemde yapılan akademik çalışmalardan istifade edilerek tespit edilmeye çalışılmıştır. Bu bağlamda tespit edilen; masum insanların cezalandırılmasının önüne geçmek için ceza vermede ihtiyatı hareket edilmesi, adaletin gereği yerine getirilirken kimseye ayrıcalık tanınmaması, cezaların suçu önleyici mahiyette olmakla birlikte işlenen suç ile orantılı olması, suçlunun haysiyetinin ve temel haklarının ihlal edilmemesi prensiplerinin, adaletin sağlanması açısından öneminin ve gerekliliğinin ortaya konması amaçlanmıştır.

Anahtar Kelimeler: İslam Hukuku, Ceza, Cezalandırma Esasları, Ceza Hükmü, Cezanın Infazı. 
Abstract: Maintaining the order and security of a community and protecting individuals rights are subjected to the existence of a fair criminal law system. Therefore, the criminal law system must have some basic principles. The penal system under Islamic law, where the supremacy of justice is considered-the main purpose, has principles to achieve the relevant goal. On the other hand, the penalty phase of the offender includes the determination of equivalent punishment of a perpetrated crime and its imposing. In this study, the essentials and principles, that should be observed in both phases according to Islamic criminal law, have been tried to be determined by making use of the two main elements of Islamic law sources -Quran and Sunnah- figh sources and contemporary academic studies conducted on the subject. In this context, it is aimed to reveal the importance and necessity of the principles of acting cautiously in sentencing in order to prevent the punishment of innocent people and impose a proportional penalty to the crime while its preventing, not to privilege while administering the required justice or not to violate the dignity and fundamental rights of the offender in terms of ensuring justice.

Keywords: Islamic Law, Punishment, Principles of Punishment, Penal Provision, Execution of Punishment Imposition of Penalty.

\section{Giriş}

Ceza hukukunun hukuk sistemleri içerisinde ayrı bir yeri ve önemi bulunmaktadır. Çünkü tabiatı itibariyle toplumsal bir varlık olan insanın, bulunduğu toplumda huzur ve güven içinde yaşayabilmesi için toplumsal düzeni koruyacak kurallara ve toplum fertlerinin birbirlerinin haklarını çiğnemelerine engel olacak yaptırımlara her zaman ihtiyaç duyulmuştur. Bu sebeple insanlar aile, kabile, aşiret gibi topluluklar halinde yaşadıkları ve henüz devlet telakkisine sahip olmadıkları dönemlerde bile kendi sosyal düzenlerini sağlayan ve toplum fertlerinin haklarını koruyan bir cezalandırma sistemine sahip olmuşlardır. ' Zamanla devlet kavramının ortaya çıkması ve toplumların devlet egemenliğine bağlı olarak yaşamaya başlamasıyla birlikte daha düzenli hukuk sistemleri ortaya çıkmış ve ceza hukuku bu hukuk sistemleri içerisinde önemli bir hukuk dalı olarak yerini almıştır.

Fert ve toplumların güvenliğini sağlama ve insanların hak ve özgürlüklerini koruma hususunda en etkili alan olması sebebiyle ceza hukukunun, emniyeti, temel hak ve özgürlükleri garanti edecek prensipleri bünyesinde barındırması büyük önem arz etmektedir. ${ }^{2}$ Bir ceza sistemi bu prensiplere bağlı olduğu ölçüde toplumda adaletin sağlanmasına katkıda bulunabilecektir. İlahî menşeli olan İslam hukukunun cezalandırma sisteminde riayet edilen prensip ve esaslar bu bağlamda üzerinde durulması gereken önemli bir mevzudur.

Klasik dönem fıkıh kitaplarında konular meseleci bir tarzda ele alınmış olup, fıkhî meselelerle ilgili genel ilke ve esaslar çoğunlukla bir bütün halinde ortaya

1 Ali Bardakoğlu, “Ceza”, Türkiye Diyanet Vakfı İslam Ansiklopedisi (İstanbul: TDV Yayınları, 1993), 7/470-478.

2 Hilal Özay, İslâm Ceza Hukukunun Temel Prensipleri (Ankara: İksad Yayınevi, 2019$), 2$. 
konmamıştır. İslam hukukunun diğer alanlarında olduğu gibi ceza hukuku alanında da aynı durum görülmektedir. Bununla birlikte fakihlerin ictihadlarında, hüküm verilirken hangi ilke ve esaslara dayanıldığına dair birçok işaret bulmak mümkündür. Çağdaş dönem İslam hukukçuları gerek naslardan gerekse müctehidlerin ictihadlarındaki işaretlerden yola çıkarak, İslam hukukunun muhtelif alanlarıyla ilgili genel ilke ve esasları ortaya koyan müstakil eserler kaleme almışlardır. İslam ceza hukukuyla ilgili olarak da bu tarz çalışmalar yapılmıştır. Muhammed Ebû Zehre'nin "el-Cerîme ve'l-ukûbe fi'l-fıkhi'l-İslâmî", Ahmed Fethî Behnesî'nin "Medhalü'l-fıkhi'l-cinâiyyi'l-İslâmî", Abdülkâdir Ûdeh'in "et-Teşrîu'lcinâiyyü'l-İslâmî" isimli kitapları bu tür çalışmalara dair önemli örneklerdir. Ülkemizde de bu konuda çok sayıda çalışma yapılmış olup, Abdullah Çolak'ın "İslam Ceza Hukuku”, Yaşar Yiğit'in "İslam Ceza Hükümlerinin Yürürlüğü”, Cevat Akşit'in "İslam Ceza Hukuku ve İnsani Esasları" adlı eserleri bunlara dair örneklerden bazılarıdır. Bunların dışında da gerek İslam ceza hukukunun genel ilkelerini konu edinen, gerekse belli bir hukuki kavramı veya ilkeyi İslam ceza hukuku açısından inceleyen birçok Türkçe ve Arapça akademik çalışma yapılmıştır.

Bu çalışmayla hem klasik fıkıh kitaplarının ilgili bölümlerinde yer alan suç ve cezalarla ilgili fıkhî hüküm ve ictihadlardan, hem de İslam ceza hukukunun genel prensipleriyle ilgili modern dönemde yapılmış çalışmalardan yararlanılarak, spesifik olarak İslam hukukuna göre cezalandırmada gözetilmesi gereken esaslar ortaya konmaya çalışılacaktır. Bu suretle İslam hukukunun ceza felsefesinin daha iyi kavranmasına katkı sağlamak amaçlanmıştır.

Makalede cezalandırma ile kastedilen yargı tarafından cezaya hükmedilmesi ve verilen cezanın infaz edilmesi aşamalarıdır.

\section{Cezaya Hükmedilirken Gözetilmesi Gereken Esaslar}

İslam hukukunda yargı makamının suça karşılık ceza belirleme yetkisi bazı hüküm, kural ve ilkelerle sınırlandırılmıştır. Bazı suçların cezası doğrudan Şâri' tarafından vaz' edilmiştir. Had adı verilen bu cezaların şekli ve miktarı naslarla beyan edilmiş olup, hâkimin bu cezaları gerektiren suçlar karşısında takdir yetkisi bulunmamaktadır. ${ }^{3}$ Insan öldürme ve yaralama suçlarının cezası da Şâri' tarafından doğrudan tayin edilmiş olmakla beraber, bu suçlarda mağdur tarafa affetme yetkisi verilmiştir. ${ }^{4}$ Hâkimin bu tür suçlarda da takdir yetkisi yoktur. Bunların dışında kalan, cezası Şâri' tarafından belirlenmemiş suçlara karşılık olarak ise suçluya ta'zîr adı verilen ceza türü uygulanmaktadır. Ta'zîr cezalarını belirlemede hâkimin takdir yetkisi vardır. ${ }^{5}$ Ancak bu takdir yetkisi de sınırsız olmayıp belli ilke ve esas-

3 Abdülkerim Zeydân, el-Medhal li dirâseti'ş-şerîati'l-Islâmiyye (Beyrut: Müessesetü'r-Risâle Nâş̧irûn, 1431/2010), 386; Ahmed Fethî Behnesî, Medhalü'l-fıkhi'l-cinâiyyi'l-Islâmî (Beyrut: Dâru'ş-Şurûk, 1409/1989), 21; Muhammed Ebû Zehre, el-Cerîme ve'l-ukûbe fi'l-fikhi'l-Islâmî (Kahire: Dâru'l-Fikri'l-Arabî, 1998), 44.

4 Abdülkâdir Ûdeh, et-Teşrîu'l-cinâiyyü'I-İslâmî (Beyrut: Dâru'l-Kitâbi'l-Arabî, ts.), 1/79. Ayr. bk. el-Bakara 2/178.

5 Muhammed Emîn b. Ömer İbn Âbidîn, Reddü'l-muhtâr 'ale'd-Dürri'l-muhtâr (Beyrut: Dâru'l-Fikr, 1412/1992), 4/60; Zeydân, el-Medhal, 392; Ûdeh, et-Teşrîu'l-cinâî, 1/80. 
lara tabidir. Bu ana başlık kapsamında gerek had ve kısas, gerekse ta'zîr cezasına hükmedilirken riayet edilmesi gereken ilke ve esaslar ele alınacaktır.

\subsection{Berâet-i Zimmet Asıldır illkesi}

Mecelle'nin 8. maddesinde yer alan bu ilke, yaratılışları itibariyle insanların zimmetlerinin ${ }^{6}$ başkalarına ait herhangi bir hak ile dolu olmadığını ifade etmektedir. ${ }^{7}$ Yani her insan, zimmetinde kimseye ait bir hak bulunmaksızın dünyaya gelmekte, başkasına ait hakların kişinin zimmetinde yer etmesi ancak gerçekleştirdiği hukuki işlemler veya hukuki fiiller sonucunda meydana gelmektedir. Bir kimse hakkında bu asıl durumun aksini iddia eden kişinin iddiasını delille ispat etmesi istenir. ${ }^{8}$ İslam hukukunun temel ilkelerinden biri olan bu kaide, aksi ispatlanmadığı sürece hiçbir insanın hukuken borçlu veya suçlu sayılamayacağını açıkça ortaya koymaktadır. Bu bakımdan kaide borçlar hukukunu olduğu gibi ceza hukukunu da ilgilendirmektedir.

Kaidenin ceza hukukunu ilgilendiren boyutu modern hukuktaki "masumiyet karinesi" ilkesine tekabül etmektedir. Bu ilke, kendisine suç isnad edilen kişinin suçluluğu kesin hükümle sabit olmadıkça masum sayılmasına yönelik bir insan hakkını ifade etmektedir. ${ }^{9}$ Adil yargılanma hakkının bir parçası sayılan masumiyet karinesi evrensel bir hukuk ilkesi olarak kabul edilmektedir. ${ }^{10}$ İslam ceza hukukunda da bu ilkenin ceza muhakemesinde temel bir esas olarak benimsendiği net bir şekilde görülmektedir.

Öncelikle İslam'ın adalete verdiği büyük önem ve adaletin tesisini emreden naslar, kanaatimizce İslam hukukunda bu ilkenin varlığının en bariz delillerindendir. Bu bağlamda şu ayeti zikredebiliriz: "Ey iman edenler, Allah için hakkı ayakta tutan, adaletle şahitlik eden kimseler olun. Bir topluluğa duyduğunuz öfke, sizi adaletsiz davranmaya itmesin. Adaletli olun... ${ }^{\prime 11}$ Ayet, yargılama ve hüküm verme konumunda olanların öfke, kin, intikam gibi kişisel duygularının verecekleri hükme tesir etmesine fırsat vermemeleri, hüküm verirken yalnızca adaleti gerçekleştirme gayesiyle hareket etmeleri gerektiğini göstermektedir. Bu da, hâkimin sanık hakkındaki hükmünü hiçbir merciin etkisi altında kalmaksızın tamamen deliller üzerine bina etmesini, delil olmaksızın şüphe, itham ve şahsi düşüncelerle ceza vermemesini zorunlu kılmaktadır. Delile dayanmaksızın zan ve tahmin

6 Fıkhî bir terim olarak zimmet: İnsanı hak ve borçlara muhatap ve ehil kılan manevi bir vasıf olup, modern hukuktaki kişilik kavramına tekabül etmektedir. (Mehmet Erdoğan, Fıkıh ve Hukuk Terimleri Sözlüğü (İstanbul: Ensar Neşriyat, 2010), "Zimmet", 621; Eyyüp Said Kaya - Hasan Hacak, "Zimmet", Türkiye Diyanet Vakfı Islam Ansiklopedisi (İstanbul: TDV Yayınları, 2013), 44/424-428.)

7 Ahmed b. Muhammed ez-Zerkâ, Şerhu'I-kavâidi'I-fıkhiyye (Dımaşk: Dâru'l-Kalem, 1430/2009), 105.

8 Ali Haydar Efendi, Düreru'I-hükkâm şerhu Mecelleti'l-ahkâm (b.y.: Dâru'I-Cîl, 1411/1991), 1/25.

9 Tugay Çatlı, Yargı Kararları Işı̆ı̆ıda Ceza Muhakemesinde Masumiyet Karinesi (Antalya: Antalya Bilim Üniversitesi, Lisansüstü Eğitim Enstitüsü, Yüksek Lisans Tezi, 2020), 5.

10 Pınar Memiş, Adil Yargılanma Hakkının Unsuru Olarak Masumiyet Karinesi (İstanbul: Galatasaray Üniversitesi, Sosyal Bilimler Enstitüsü, Yüksek Lisans Tezi, 2003), 4.

11 el-Mâide 5/8. 
ile hareket etmeyi yasaklayan Kur'an ve Sünnet nasları da ilkenin dayanakları arasında sayılabilir. ${ }^{12}$ Mesela "Oysa onların bu konuda bir bilgileri yok; sadece zanna uyuyorlar. Zan ise asla gerçeğin yerini tutamaz"13 ayeti, zan üzerine bina edilen bir hükmün hiçbir surette hakikati ifade etmeyeceğini ortaya koymaktadır.

Öte yandan İslam ceza hukukunda sanığın kendisine atfedilen suçu işleyip işlemediğine dair şüphe bulunması halinde, sanığa had cezası uygulanamayacağı temel bir kural olarak benimsenmiştir. Nitekim Hz. Peygamber'in (s.a.v) şu hadisi bu kuralı açıkça beyan etmektedir: "Gücünüz yettiği ölçüde Müslümanlara had cezalarını uygulamayın. Eğer sanık için bir çıkış yolu varsa onu serbest bırakın. Zira hâkimin affetmede hata etmesi ceza vermekte hata etmesinden daha iyidir."14 Hz. Peygamber (s.a.v.) bizzat kendisi de bu kuralı tatbik etmiş, zina ettiğine dair güçlü şüpheler bulunmakla beraber suçu kesin delillerle ispat edilememiş bir kadına had cezası uygulamamış, kadın hakkında şöyle söylemiştir: "Eğer ben delil olmadan bir kimseye recm cezası verseydim, falan kadını recm cezasına çarptırırdım. Çünkü konuşması, tavrı ve yanına girip çıkanlar sebebiyle onda suç işlediğine dair şüphe ortaya çıkmıştır." ${ }^{\prime 15}$

Zikredilen naslar, modern hukukta masumiyet karinesinin bir unsuru ve sonucu olarak kabul edilen "şüpheden sanık yararlanır" ilkesinin, ${ }^{16}$ İslam hukukunda da benimsenen ve "berâet-i zimmet asıldır" kaidesinin gereği olan temel bir ilke olduğunu göstermektedir. ${ }^{17}$ Bu sebeple fıkhî kaynaklarda, özellikle had cezalarının, uygulanmasını güçleştiren pek çok şarta bağlandığı, en küçük bir şüphenin bile cezayı düşürücü bir unsur olarak kabul edildiği görülmektedir. Mesela Hanefî ve Şâfi'îlerin de içinde bulunduğu fakihlerin çoğunluğu, bir kimseden içki kokusunun gelmesini had cezası verilmesi için yeterli bir delil olarak görmemiş, suçun sübutunda şüphe bulunduğu için böyle bir durumda had cezasının uygulanamayacağını belirtmişlerdir. ${ }^{18}$ Yine Hanefî ve Şâfi'î mezheplerine göre, maksadın ne olduğuna dair şüphe barındırdıkları için kinayeli lafızlar ve ta'rîz bildiren ifadeler sebebiyle zina iftirası suçu sabit olmamakta ve hadd-i kazf uygulanmamaktadır. ${ }^{19}$

12 Mustafa Cevat Akşit, İslam Ceza Hukukunda Insanî Esaslar Üzerine Bir Deneme (Erzurum: Atatürk Üniversitesi, Sosyal Bilimler Enstitüsü, Doktora Tezi, 1975), 89.

13 en-Necm 53/28.

14 Ebû İsâ Muhammed b. İsâ et-Tirmizî, el-Câmiu's-sahîh, thk. Ahmed Muhammed Şâkir vd. (Mısır: Mektebetü ve Matbaatü Mustafa el-Bâbî el-Halebî, 1395/1975), "Hudûd", 2 (No. 1424).

15 Ebû Abdillâh Muhammed b. Yezîd İbn Mâce el-Kazvînî, es-Sünen, thk. Şuayb el-Arnaût vd. (Beyrut: Dâru'rRisâleti'l-Âlemiyye, 1430/2009), “Hudûd”, 11 (No. 2559).

16 Çatlı, Ceza Muhakemesinde Masumiyet Karinesi, 64.

17 Akşit, i̇slam Ceza Hukukunda Insanî Esaslar, 89.

18 Alâüddîn Ebû Bekr b. Mes'ûd el-Kâsânî, Bedâiu's-sanâi' fi tertîbi'ş-şerâi' (b.y.: Dâru'l-kütübi'l-ilmiyye, 1406/1986), 7/40; Ebu'I-Velîd Muhammed b. Ahmed İbn Rüşd, Bidâyetü'l-müctehid ve nihâyetü'l-muktesıd (Kahire: Dâru'lHadîs, 1425/2004), 4/228; Şemsüddîn Muhammed b. Ahmed el-Hatîb eş-Şirbînî, Muğni'l-muhtâc ilâ ma'rifeti meânî elfâzi'I-Minhâc (b.y.: Dâru'l-Kütübi'I-IIlmiyye, 1415/1994), 5/520. Ayr. bk. Safetullah Çiçek, İslam Ceza Hukukunda Şüphe Kavramı ve Cezalara Etkisi (Van: Yüzüncü Yıl Üniversitesi, Sosyal Bilimler Enstitüsü, Yüksek Lisans Tezi, 2009), 66.

19 Kâsânî, Bedâiu's-sanâi', 7/42; Muhammed b. Ferâmerz Molla Hüsrev, Mir'âtü'l-usûl 'alâ Mirkâti'l-vusûl (İstanbul: Eser Kitabevi, ts.), 296-297; Ebû Zekeriyyâ Muhyiddîn Yahya b. Şeref en-Nevevî, Ravzatü't-tâlibîn ve umdetü'lmüftîn, thk. Züheyr eş-Şâvîş (Beyrut: el-Mektebü'l-Islâmî, 1412/1991), 8/312. 
İslam hukukunda had cezası gerektiren suçlarla ilgili davalarda davalıya kendisine atfedilen suçu işlemediğine dair yemin ettirilmemektedir. ${ }^{20}$ Bu durum yine masumiyet karinesinin bir gereğidir. Zira bu ilkeye göre kişi kesin delillerle suçu işlediği ispat edilene kadar hukuken suçsuz kabul edilmekte, dolayısıyla suçsuz olduğunu ispat etmesine gerek duyulmamaktadır. İslam yargılama hukukunda davalarda bir ispat vasıtası olarak kabul edilen "nükûl", ${ }^{21}$ suçun ispatı hususunda şüpheden tamamen uzak bir delil olmadığı için had ve kısas cezalarının verilebilmesi için yeterli bir dayanak olarak görülmemiştir. ${ }^{22}$

Çağdaş İslam hukukçularından Abdülkadir Ûdeh, şüphe halinde ceza verilmemesi kuralının had ve kısas cezalarında olduğu gibi ta'zîr cezalarında da uygulanabileceğini belirtmiş, gerekçe olarak şunu söylemiştir: "Çünkü bu kural, adaleti gerçekleştirmek ve zanlıların yararını temin etmek için vaz' edilmiştir. İster had, ister ta'zîr cezasını gerektiren bir suçla itham edilsin, her sanık adalete ve yararının gözetilmesine ihtiyaç duymaktadır." ${ }^{23}$

Netice itibariyle İslam ceza hukukunda suçu şüpheye yer kalmayacak şekilde sabit olmadığı sürece sanığa ceza vermenin, suçlu muamelesi yapmanın, çeşitli iletişim araçlarıyla sanığı topluma suçlu gibi yansıtmanın caiz olmadığını söyleyebiliriz. Bu bağlamda günümüz hukuk sistemlerinde geçici bir koruma tedbiri olarak kabul edilen tutuklu yargılama yönteminin, sanığın suçlu olduğuna dair güçlü deliller bulunup delilleri karartma ve kaçma şüphesinin olması gibi haklı sebepler olmaksızın uygulanmasının, İslam hukuku açısından meşru görülemeyeceğini söylemek mümkündür. Çünkü tutuklu yargılamanın keyfi kullanımı, insanların suçları sabit olmadan uzun tutukluluklarla cezalandırılmalarına sebep olur. Bu durum ise berâet-i zimmet asıldır ilkesiyle bağdaşmamaktadır.

\subsection{Cezanın Suç İle Orantılı OIması}

Suçluya verilecek cezanın işlediği suç ile orantılı ve ona denk bir ceza olması adaletin gereğidir. Bir insanı işlemediği bir suçtan dolayı cezalandırmak haksızlık olduğu gibi, hafif bir suç işleyen kimseyi çok ağır cezalara çarptırmak da bir hak ihlalidir. Aynı şekilde insanların hukukunu çiğneyen ve toplum düzenini bozan çok ağır suçlara karşılık hafif cezalar verilmesi de, yapılan kötülük ve haksızlıkların yapanın yanına kâr kalmasına sebep olarak adalet sistemini temelden sarsar. Bunun için İslam suç-ceza dengesine büyük önem vermiş, işlenen suçların misliyle cezalandırılması gerektiğini ortaya koymuştur.

20 Abdullah b. Mahmud el-Mevsılî, el-Muhtâr li'l-fetvâ (el-ihtiyâr şerhiyle birlikte), thk. Beşşâr Bekrî Arâbî (Dımaşk: Dâru'l-Kubâ, ts.), 1/384; Kâsânî, Bedâiu's-sanâi', 9/105-106.

21 Nükûl: "Davalı ya da davacının kendisine yöneltilen yemine yanaşmaması, yemin etmekten kaçınması" demektir. Erdoğan, "Nükûl ani'l-yemîn", 459.

22 Mevsılî, el-ihtiyâr li ta'lîli'I-Muhtâr, thk. Beşşâr Bekrî Arâbî (Dımaşk: Dâru'l-Kubâ, ts.), 1/384-385; Kâsânî, Bedâiu'ssanâi', 9/106.

23 Ûdeh, et-Teşrîu'l-cinâî, 1/216. 
Kur'an'daki şu ayet bu hususu ifade eden naslardan birisidir: "Eğer ceza verecekseniz, size yapılanın misli bir ceza verin. ${ }^{\prime 24}$ Ayet, özellikle kul hakkını ihlal eden suçlarda haksızlık yapan şahsın, başkasını uğrattığı zarara denk bir zarara uğratılmak suretiyle cezalandırılmasını öngörmektedir. Nitekim bir kimseyi haksız yere öldüren şahsa ölüm cezası uygulanırken dahi aşırıya gidilmemesi gerektiği Kur'an'da şöyle ifade edilmiştir: "Kim haksızlığa uğratılarak öldürülürse, biz onun velisine yetki vermişizdir. Ancak o da öldürmede sınırı aşmasın. ${ }^{\prime 25}$ Ayette maktulün yakınlarının talep etmesi halinde, katilin işlediği öldürme suçuna denk bir ceza olarak ölüm cezasına çarptırılacağı belirtilmiş, ancak bununla yetinmeyip katile işkence etmek gibi aşırılıklarda bulunmak yasaklanmıştır. ${ }^{26}$

İslam hukukundaki kısas kavramı esasen ceza ile suçun birbirine denk ve benzer olmasını ifade etmektedir. ${ }^{27}$ Kısas cezalarından amaç, suçlu ile mağdur arasında denkliğin sağlanmasıdır. Bunun için çeşitli sebeplerden dolayı bu denkliği sağlamak mümkün olmadığında kısas cezası sakıt olup yerine diyet takdir edilmektedir. ${ }^{28}$ Hanefî fakihlerden Kâsânî (öl. 587/1191) bu hususta şöyle söylemiştir: "Vücut dokunulmazlığına karşı işlenen öldürme dışındaki suçlarda kısas cezasının uygulanabilmesi için aranan şartlardan birisi, mağdurun vücudunda zarar verilen mahal ile buna mukabil suçlunun vücudunda kısas yapılacak mahal arasında denklik olmasıdır... Bu denkliğin sağlanamaması kısasın sübûtuna engel teşkil etmektedir."29

Kul hakkının yanında kamu hakkını da ilgilendiren, hatta genellikle kamu hakkının daha ağır bastığı had cezalarında ise, kısasta olduğu gibi suç ile ceza arasında tıpatıp eşitlik söz konusu olmamakla birlikte, bu cezaların da işlenen suça uygun ve dengeli cezalar olduğu görülmektedir. ${ }^{30}$ Ancak had cezasını gerektiren suçlar ile cezaları arasındaki denge hissedilir miktarlarda değil, işlenen suçun doğurduğu haksızlık ve mağdurun yanında üçüncü şahıslara ve topluma verdiği zararlarla takdir edilen cezanın ölçüsü arasında aranmaktadır. ${ }^{31}$ Öte yandan zina boyutuna gelmemiş öpüşme, kucaklaşma gibi haram cinsel fiillere had cezası verilmemesi, ${ }^{32}$ belli bir kıymetin altındaki eşyaların çalınması halinde hırsızın

24 en-Nahl 16/126.

25 el-ìsrâ $17 / 33$.

26 Muhammed b. Abdullah Ebû Bekr İbnü'l-Arabî, Ahkâmü'l-Kur'ân, thk. Muhammed Abdülkâdir Atâ (Beyrut: Dâru'l-Kütübi'I-IIlmiyye, 1424/2003), 3/197.

27 Muhammed Revvâs Kal'acî - Hâmid Sâdık Kanîbî, Mu'cemu luğati'l-fukahâ (b.y.: Dâru'n-Nefâis, 1408/1988), "Kısâs", 364.

28 Mustafa Özgür, "İslam Ceza Hukukunda Infazın Temel IIlkeleri”, Artvin Çoruh Üniversitesi Ilahiyat Araştırmaları Dergisi 3/1 (2019), 57.

29 Kâsânî, Bedâiu's-sanâi', 7/297.

30 Murat Polat, "İslâm Ceza Hukukunun Karakteristik Özelliklerinden Bazı Örnekler", Amasya Üniversitesi Ilahiyat Fakültesi Dergisi 9 (Aralık 2017), 268.

31 Yaşar Yiğit, "İslâm Hukukunda Suç-Ceza Dengesinin Adaletle Illişkisi", Diyanet IIlmî Dergi, 56 (2020), 84; Bardakoğlu, "Ceza", 7/470-478.

32 Ebu'l-Hasen Burhâneddîn Ali b. Ebû Bekir el-Merğînânî, el-Hidâye, thk. Tallâl Yusuf (Beyrut: Dâru Ihyâi't-Türâsi'lArabî, ts.), 2/339; Ebû İshâk İbrahim b. Ali eş-Şîrâzî, el-Mühezzeb fî fikhi'I-İmâm eş-Şấfi'î (b.y.: Dâru'I-Kütübi'lİlmiyye, ts.), 3/373; Muvaffakuddîn İbn Kudâme, el-Muğnî (b.y.: Mektebetü'l-Kahire, 1388/1968), 9/176. 
elinin kesilmemesi, ${ }^{33}$ zina iftirası dışında kalan hakaret suçlarında had cezasının uygulanmaması, ${ }^{34}$ bu gibi suçlarda daha hafif bir ceza olan ta'zîr cezasına hükmedilmesi ${ }^{35}$ gibi hususlar da İslam hukukunda suç-ceza dengesinin gözetilmesi ilkesinin benimsenmiş olduğunu göstermektedir. Bu bağlamda Kâsânî'nin şu ifadesini aktarmakta fayda görüyoruz: "Had, kâmil bir cezadır. Dolayısıyla bu cezanın verilmesi, kâmil bir suçun işlenmiş olmasını gerektirmektedir." ${ }^{\prime 36}$

Suç işleyene ceza takdir edilirken suçun işlenme sebebinin ve failin içinde bulunduğu şartların dikkate alınması da, suç-ceza dengesinin gözetilebilmesi için gereklidir. Hz. Ömer'in (r.a.) halifeyken kıtlık yaşandığı yıl hırsızlık yapan kimselere el kesme cezasını uygulatmaması ve "Bir salkım hurma çalmaktan dolayı el kesilmez. Kıtlık yaşanan bir yılda da el kesilmez" demesi, ${ }^{37}$ İslam hukukunda "cezanın suç ile orantılı olması" ilkesine verilen ehemmiyeti göstermesi bakımından önemli bir örnektir.

İslam hukukunda cezada hafifletici bir sebep kabul edilen ve had yerine ta'zîr cezasının uygulanmasına sebep teşkil eden durumlardan birisi de, suçlunun yaptığı fiilin suç olduğunu bilmemesidir. Bundan dolayı bazı fakihler, aralarında şer'an evlenme engeli olduğunu bilmeden bir kadınla nikâhlanıp cinsî münasebette bulunan kişiye zina haddinin uygulanmayacağını, ancak canını acıtacak bir ta'zîr cezası verileceğini belirtmişlerdir. ${ }^{38}$ İslam hukukçularının bu ve benzeri yaklaşımlarında, suç olduğu herkesçe bilinemeyebilen fiilleri meşru zannederek işleyenlere eksiksiz ceza verilmesinin suç-ceza dengesi açısından uygun bulunmadığı görülmektedir.

Öte yandan suçun ağırlığı nispetinde takdir edilecek cezanın ağırlaşması da, cezanın suç ile orantılı olması ilkesinin bir gereğidir. İslam hukukunda bu durumun en bariz örneklerinden birisi, kamu düzenini bozan ve insanların can, mal ve ırz güvenliğini tehdit eden eşkıyalık suçu için öngörülen cezalarda görülmektedir. Kur'an'ın ilgili ayetinde bu suçun cezası şöyle ifade edilmiştir: "Allah ve peygamberine karşı savaşanların ve yeryüzünde bozgunculuk çıkarmaya çalışanların cezası ancak öldürülmeleri veya asılmaları yahut el ve ayaklarının çapraz olarak kesilmesi

33 Mevsılî, el-ihtiyâr, thk. Beşşâr Bekrî Arâbî, 2/325-326; Şîrâzî, el-Mühezzeb, 3/373; ỉbn Kudâme, el-Muğnî, 9/176. Ayr. bk. Ebû Abdillâh Muhammed b. İsmâil el-Buhârî, el-Câmiu's-Sahîh, thk. Muhammed Züheyr b. Nâsır enNâsır (Beyrut: Dâru Tavkı'n-Necât, 1422/2001), "Hudûd", 14 (No. 6794).

34 Ebû Bekr b. Ali el-Haddâd, el-Cevheretü'n-neyyire (b.y.: el-Matbaatü'l-Hayriyye, 1322/1904), 2/161; Şîrâzî, elMühezzeb, 3/373; İbn Kudâme, el-Muğnî, 9/176.

35 Zeynüddîn b. İbrahim İbn Nüceym el-Mısrî, el-Bahru'r-râik (b.y.: Dâru'l-Kitâbi'l-i̇slâmî, ts.), 5/18; Haddâd, elCevhere, 2/155, 161; Mevsılî, el-ihtiyâr, thk. Beşşâr Bekrî Arâbî, 2/310; Şîrâzî, el-Mühezzeb, 3/373; İbn Kudâme, el-Muğnî, 9/176.

36 Kâsânî, Bedâiu's-sanâi,' 7/34.

37 Ebû Abdillâh Muhammed b. Ebî Bekr İbn Kayyim el-Cevziyye, i'lâmü'l-muvakkîin an Rabbi'l-âlemîn, thk. Ebû Ubeyde Meşhûr b. Hasen Âl-i Selmân (Suudi Arabistan: Dâru İbni'l-Cevzî, 1423/2002), 4/350.

38 Muhammed b. Ali Alâüddîn el-Haskefí, ed-Dürrü'l-muhtâr şerhu Tenvîri'l-ebsârve câmi'i'l-bihâr, thk. Abdülmün'im Halil İbrahim (b.y.: Dâru'I-Kütübi'I-IIlmiyye, 1423/2002), 309; İbn Âbidîn, Reddü'l-muhtâr, 4/24; İbn Kudâme, elMuğnî, 9/57. 
ya da bulundukları yerden sürgün edilmeleridir..." ${ }^{\prime 39}$ Ayette bu suçu işleyenler için dört tür ceza öngörülmüştür. İslam hukukçularının çoğunluğu bunu, bu suçun cezasının yargı makamının takdirine bırakıldığı ve hâkimin suçun mahiyeti ve ağırlığı ile mütenasip bir ceza takdir etmekle yükümlü olduğu şeklinde yorumlamışlardır. Buna göre suçun sadece insanların yolunu kesip onları korkutmak suretiyle gerçekleşmesi halinde suçluya sürgün, hapis gibi daha hafif cezalar verilirken; insanların mallarını zorla alma, öldürme gibi haksız fiillerin işlenmiş olması durumunda ise ölüm, el ve ayakların çaprazlama kesilmesi gibi ağır cezalar söz konusu olmaktadır. ${ }^{40}$

Verilecek cezanın suç ile orantılı olabilmesi için cezaya konu olan suçun ilk kez mi yoksa mükerrer olarak mı işlendiğinin de dikkate alınması gerekmektedir. Zira bir kimsenin ceza aldıktan sonra aynı suçu tekrar işlemesi, bu kimsenin cezadan ders almadığını ve söz konusu suçu işleme hususunda eğilim kazandığını göstermektedir. Bu kimsenin suçu ile ilk kez suç işleyen kişinin suçu ağırlık bakımından aynı olmadığından, ikisine verilecek cezanın aynı olması suç-ceza dengesini zedeleyebilecektir. ${ }^{41}$ Bunun için İslam hukukçuları hâkimin gerekli durumlarda caydırıcılığı artırmak için suçluya had cezasına ilave olarak ta'zîr cezası verme, cezanın uygulandığı aletin vasfını değiştirme gibi uygulamalara gidebileceğini öngörmüşlerdir. ${ }^{42}$

Özetle ifade etmek gerekirse, İslam ceza hukukunda gerek kısas gerekse had cezalarında, cezanın suç ile orantılı olması ilkesinin var olduğu görülmektedir. Bunun için had ve kısas cezalarını gerektiren suçların dışında kalan, cezası naslarda belirtilmeyip hâkimin takdirine bırakılmış suçlarda da, hâkimin gerekli ta'zîr cezasını belirlerken bu ilkeye riayet etmesi, orantısız ceza vermekten kaçınması gerekmektedir.

Öte yandan cezanın suç ile orantılı olması modern hukukta da ceza hukukunun önemli bir ilkesi olarak kabul edilmektedir. Nitekim 5237 sayılı Türk Ceza Kanunu'nun 3. maddesinin 1. fıkrasında şöyle bir düzenleme yer almaktadır: "Suç işleyen kişi hakkında işlenen fiilin ağırlığıyla orantılı ceza ve güvenlik tedbirine hükmolunur." 43

39 el-Mâide 5/33.

40 Kâsânî, Bedâiu's-sanâi', 7/93; Nevevî, Minhâcü't-tâlibîn ve umdetü'I-müftîn, thk. İvaz Kasım Ahmed İvaz (b.y.: Dâru'l-Fikr, 1425/2005), 301-302; Mansûr b. Yunus el-Buhûtî, Keşşâfü'I-kınâ' 'an metni'l-iknâ' (b.y.: Dâru'l-Kütübi'lİlmiyye, ts.), 6/150; İbn Kudâme, el-Muğnî, 9/150.

41 Murat Polat, İslam Ceza Hukukunda Suç ve Ceza Arasındaki Denge (Erzurum: Atatürk Üniversitesi, Sosyal Bilimler Enstitüsü, Doktora Tezi, 2015), 60.

42 Bkz. Ûdeh, et-Teşrîu'l-cinâî, 1/131-132; Polat, Suç ve Ceza Arasındaki Denge, 60-61.

43 Türk Ceza Kanunu (TCK), Resmî Gazete 25611 (26 Eylül 2004), Kanun No. 5237, md. 3/1. Modern hukukta "cezanın orantılı olma" ilkesiyle ilgili ayrıntılı bilgi ve değerlendirme için bkz. Mustafa Çiçek, Kısa Süreli Hapis CezaIarına Seçenek Olarak Sunulan Yaptırımların Değerlendirilmesi (İstanbul: İstanbul Üniversitesi, Adli Tıp Enstitüsü, Yüksek Lisans Tezi, 2019), 41-42. 


\subsection{Cezanın Caydırıcı Olması}

İslam hukukunda en ağır cezalar had cezaları ve kısastır. Bu cezalar, hayata son vermeyi de içine alan, bedene yönelik çok ağır sonuçları olan yaptırımlardır. Belli suçlara bu tür ağır cezalar öngörülmesi, İslam ceza hukukunun benimsediği esaslardan biri olan caydırıcılık ilkesinin bir gereğidir. Hanefî fakih Zeylaî (öl. 743/1343), ağır yaptırımlar içeren belli cezalar için "had" denilmesinin sebebini şöyle açıklamaktadır: "Bu cezalar, kendilerine sebep olan suçların alışkanlık edilerek işlenmesini engelleyici nitelikte olduğu için kendilerine "hadler" denilmiştir."44 Zira had kelimesi sözlükte "menetmek" anlamına gelmektedir. ${ }^{45}$ Hadlerle uygulanan ağır ceza, suçlunun aynı acıyı tekrar yaşamamak için had gerektiren suçu bir daha işlememesine vesile olduğu gibi, cezanın infazına şahit olanların da aynı akıbete uğramamak için bu tür suçlardan kaçınmalarını sağlamaktadır. ${ }^{46}$

İslam ceza hukukunda had ve kısas cezalarının, korunması zaruri beş temel esası ihlal eden suçlara karşılık olarak vazedilen cezalar olduğu görülmektedir. Can, din, mal, nesil ve aklın korunması fert ve toplumlar için zaruri ve hayati bir ihtiyaç olduğu için, bu unsurların muhafazası için bunlara yönelik suçlara caydırıcılık açısından en ağır cezalar öngörülmüşsür. ${ }^{47}$

Had cezaları suça dair en küçük bir şüphe halinde düşürülen, mümkün olduğu kadar verilmekten kaçınılan cezalar olmakla birlikte, aynı zamanda kendilerini gerektiren suçlar sabit olduğunda tatbiki hususunda hiçbir surette taviz verilmeyen cezalardır. Nitekim had cezaları İslam hukukunda, Allah hakkı olarak sabit olan miktarı belirli cezalar olarak tanımlanmış, ${ }^{48}$ sübut bulduktan sonra hiç kimseye bu cezaları affetme, hafifletme, farklı bir cezayla değiştirme yetki ve izni verilmemiştir. ${ }^{49}$ Hatta had cezalarının uygulanmaması için aracı olmanın, Allah'a isyan etmek sayılacağı Hz. Peygamber'in (s.a.v.) hadisinde belirtilmiştir. ${ }^{50}$ Ayrıca Kur'an'da, had cezaları söz konusu olduğunda acıma duygusunun etkisi altında kalınmaması gerektiği şöyle ifade edilmiş̧tir: "Zina eden kadın ve zina eden erkeğin her birine yüz kamçı vurun. Allah'a ve ahiret gününe inanıyorsanız, Allah'ın dinini uygulama hususunda onlara karşı sizi acıma duygusu tutmasın." ${ }^{\prime 51}$ Suç sabit olduktan sonra had cezalarının uygulanması hususundaki bu kararlı ve tavizsiz yaklaşım, caydırıcılık ilkesini teyit eden ve cezaların caydırıcılığını sağlayan önemli bir etkendir.

44 Osman b. Ali Fahruddîn ez-Zeyla'î, Tebyînü'l-hakâikşerhu Kenzi'd-dekâik, (Bulak: el-Matbaatü'l-Kübrâ el-Emîriyye, 1313/1895), 3/163.

45 Kal'acî-Kanîbî, “Had”, 176.

46 Kâsânî, Bedâiu's-sanâi', 7/33; Zeydân, el-Medhal, 384.

47 Ebû Zehre, el-Cerîme ve'l-ukûbe, 18.

48 Merğînânî, el-Hidâye, thk. Tallâl Yusuf, 2/339; Mevsılî, el-Muhtâr, thk. Beşşâr Bekrî Arâbî, 2/296; Şirbînî, Muğni'lmuhtâc, 5/460.

49 Ûdeh, et-Teşrîu'l-cinâî, 1/81-82.

50 Hadiste şöyle geçmektedir: "Kimin aracılığı Allah’ın hadlerinden birinin uygulanmasının önünde engel olursa, bu kişi Allah'la zıtlaşmış olur." Ebû Dâvûd Süleyman b. el-Eş'as es-Sicistânî, es-Sünen, thk. Şuayb el-ArnaûtMuhammed Kâmil Karabelli (b.y.: Dâru'r-Risâleti'l-Âlemiyye, 1430/2009), “Akzıye”, 14 (No. 3597).

51 en-Nûr 24/2. 
Cezanın caydırıcı olması ta'zîr cezaları için de geçerli bir ilkedir. İslam hukukçuları ta'zîr cezalarının had cezaları kadar ağır olmaması gerektiğini, bununla birlikte hâkimin ta'zîr cezası verirken suç işleyen kişinin durumunu dikkate alıp, onu suçtan alıkoyacağı kanaatine vardığı bir ceza takdir etmesi gerektiğini ifade etmişlerdir. ${ }^{52}$ Buna bağlı olarak muhatabın durumuna göre uygulanacak ta'zîr cezalarını sınıflara ayırmışlardır. Suçu tekrar etmemesi için sadece uyarılması yeterli bulunan toplumun ileri gelenlerine uyarı cezası verilmesi yeterli görülürken, bu yolla suçu terk etmesi muhtemel görülmeyenlere ise hapis vb. te'dîb edici farklı cezaların uygulanabileceği belirtilmiştir. ${ }^{53}$ Bütün bunlar, İslam ceza hukukunda "caydırıcılık ilkesinin" suçlulara ceza verilirken riayet edilmesi gereken temel bir esas olduğunu göstermektedir.

\subsection{Hukuk Önünde Eşitlik İlkesi}

Adaletin gereklerinden birisi de, konumu ne olursa olsun herkesin ayırım yapılmaksızın hukuk kuralları önünde eşit kabul edilmesidir. Modern hukukta evrensel bir hukuk ilkesi olarak görülen eşitlik ilkesi, Türkiye Cumhuriyeti Anayasasının 10. maddesinde "Kanun Önünde Eşitlik" başlığı altında şöyle ifade edilmiştir: "Herkes, dil, ırk, renk, cinsiyet, siyasi düşünce, felsefi inanç, din, mezhep ve benzeri sebeplerle ayırım gözetilmeksizin kanun önünde eşittir." ${ }^{44}$

İslam ceza hukukunda da bu ilkenin temel bir esas olarak mevcut olduğu bariz bir şekilde görülmektedir. Özellikle had ve kısas cezalarında, hiçbir inanç, soy, mevki, sosyal sınıf ve gelir grubuna mensup olmak ayrıcalık sebebi sayılmamakta, bu durum hiçbir surette suçu sabit olan kimseye gerekli cezanın verilmesine engel teşkil etmemektedir. Nitekim Hz. Peygamber (s.a.v.), hırsızlık yapan soylu bir kadına ceza verilmemesi için aracılık edenlere tepki göstermiş ve şöyle söylemiştir: "Sizden öncekiler ancak şundan dolayı helâk oldular: Onlar içlerinde soylu birisi hırsızlık yaptığında ona ceza vermez, zayıf birisi hırsızlık yaptığında ise onu cezalandırırlardı. Allah'a yemin olsun ki, Muhammedin kızı Fâtıma hırsızlık yapsaydı onun da elini kestirirdim. ${ }^{\prime \prime 55} \mathrm{~Hz}$. Peygamber'in (s.a.v.) bu yaklaşım ve duruşu, İslam ceza hukukunun, hukukun üstünlüğü ve hukuk önünde eşitlik esasına dayalı olduğunu göstermektedir.

İslam ceza hukukunda, hür-köle, kadın-erkek, büyük-küçük, müslüman-zimmî ayırımı olmaksızın devletin bütün vatandaşlarının temel hakları koruma altına alınmıştır. Bu haklara tecavüzde bulunulması halinde suçluyla mağdur arasındaki statü farkına bakılmaksızın suçluya gerekli cezanın verilmesi esastır. Nitekim İslam hukukçuları, İslam ülkesinin vatandaşı olan bir gayri müslimin (zimmî) malını çalan bir Müslümana el kesme cezası verileceği hususunda ittifak etmiş-

52 Kemâlüddîn Muhammed b. Abdülvâhid İbnü'l-Hümâm, Fethu'l-Kadîr (b.y.: Dâru'l-Fikr, ts.), 5/345.

53 Kâsânî, Bedâiu's-sanâi', 7/64; Şirbînî, Muğni'l-muhtâc, 5/522.

54 Türkiye Cumhuriyeti Anayasası, Resmî Gazete 17863 (9 Kasım 1982), Kanun No. 2709, md. 10.

55 Buhârî, “Hudûd”, 12 (No. 6787); Ebû Dâvûd, (Hudûd, 4 No. 4373). 
lerdir. ${ }^{56}$ Hanefî fakihler, zimmîlerin mal dokunulmazlığı gibi can dokunulmazlığı hususunda da Müslümanlardan farksız olduklarını gerekçe göstererek, zimmîyi öldürmenin Müslümanı öldürmek gibi kısas cezası gerektiren bir suç olduğunu söylemişlerdir. ${ }^{57}$ Kölelik sisteminin dünyada mevcut olduğu dönemlerde, İslam ceza hukukunda bu kesimle ilgili hükümler de düzenlenmiştir. Özellikle Hanefî fakihler kölelerin can dokunulmazlığına yapılan saldırının, hür kimselere yapılan saldırıda olduğu gibi kısas cezasını gerektireceğini belirtmişlerdir. ${ }^{58}$ Bütün bunlar, İslam ceza hukukuna göre, hukuk önünde eşitlik açısından suça maruz kalan kimselerin kimlikleri arasında ayırım yapılamayacağını, kime karşı işlenirse işlensin kişilere karşı işlenen suçların cezasız kalmayacağını göstermektedir.

Kur'an'da, kişinin en yakınlarının aleyhine bir sonuç doğuracak dahi olsa adaletin gereğinin yerine getirilmesi gerektiği vurgulanmaktadır. Illgili ayette şöyle geçmektedir:

"Ey iman edenler, kendinizin veya anne baba ve yakınlarınızın aleyhine bile olsa, adaleti yerine getiren, Allah için şahitlik eden kimseler olun. Hakkında şahitlik yapılacak kişi ister zengin ister fakir olsun. Allah onlara sizden daha yakındır. Öyleyse arzunuza uyup adaletten sapmayın. Eğer şahitlikte hakikati çarpıtır veya şahitlikten kaçınırsanız, bilesiniz ki Allah yaptıklarınızdan haberdardır. ${ }^{\prime 159}$

Ayette yargılama sırasında davanın taraflarının kimliklerine bakılmaması gerektiği ifade edilerek, hukuk önünde eşitlik ilkesine riayetin önemine güçlü bir şekilde vurgu yapılmaktadır.

Hiç kimsenin işlediği suçlara karşılık dokunulmazlık hakkının bulunmaması da hukuk önünde eşitlik ilkesinin gereklerindendir. ${ }^{60}$ İslam hukuku, devleti yönetenler ile vatandaşları, kanunların kendileri hakkında geçerli olması ve işledikleri suçlardan sorumlu tutulmaları açısından eşit tutmuştur. ${ }^{61}$ Nitekim İslam tarihinde halifelerin, devlet başkanlarının, valilerin mahkeme önünde yargılandıklarına dair çok sayıda örnek bulunmaktadır. ${ }^{62}$

Ancak devletin en üst yetkilisi durumundaki devlet başkanına yalnızca cezaların nasıl infaz edileceği hususunda bazı İslam hukukçularınca farklı yaklaşım-

56 İbn Rüşd, Bidâyetü'l-müctehid, 4/182. Ayr. bk. Muhammed b. Ahmed Şemsüleimme es-Serahsî, el-Mebsût (Beyrut: Dâru'I-Ma'rife, 1414/1993), 9/181; Nevevî, Minhâc, thk. İvaz Kasım Ahmed İvaz, 300; İbn Kudâme, el-Muğnî, 9/132.

57 İbn Rüşd, Bidâyetü'l-müctehid, 4/181-182. Ayr. bk. Molla Hüsrev, Dürerü'l-hükkâm şerhu Ğureri'l-ahkâm (b.y: Dâru İhyâi'I-Kütübi'l-Arabiyye, ts.), 2/91; Kâsânî, Bedâiu's-sanâi', 7/237. Ayrıntılı bilgi için bkz. Yaşar Yiğit, "islâm Ceza Hukuku Hükümleri Bağlamında Zimmîler", Diyanet Illmî Dergi, 57 (2021), 171-204.

58 Ahmed b. Muhammed Ebü'l-Hüseyn el-Kudûrî, Muhtasaru'I-Kudûrî, thk. Kâmil Muhammed Muhammed Uveyza (b.y.: Dâru'l-Kütübi'l-IImiyye, 1418/1997), 184; Merğînânî, el-Hidâye, thk. Tallâl Yusuf, 4/444; Mevsılî, el-Muhtâr, thk. Beşşâr Bekrî Arâbî, 5/26; İbn Rüşd, Bidâyetü'l-müctehid, 4/180-181.

59 en-Nisâ 4/135.

60 Yaşar Yiğit, "İslâm Ceza Hukukunda Eşitlik illkesi ve Dokunulmazlık", Kur'ân Mesajı Ilmî Araştırmalar Dergisi 13, 14, 15 (1999), 198.

61 Ûdeh, et-Teşrîu'l-cinâî, 1/317; Yiğit, “Eşitlik İlkesi ve Dokunulmazlık”, 199.

62 bk. Ûdeh, et-Teşrîu'l-cinâî, 1/318-320. 
lar ileri sürülmüştür. Mesela Hanefî mezhebinde devlet başkanına had cezasının infaz edilmeyeceği, kısas ve diyet cezalarını gerektiren suçlarda ise gereken cezanın tatbik edileceği kanaati benimsenmiştir. ${ }^{63}$ Bunun gerekçesi ise had cezalarının kamu hukukunu ilgilendiren cezalar olması ve bunları infaz yetkisinin devlet başkanına ait bulunmasıdır. Bu yaklaşıma göre devlet başkanı bu cezayı kendisine uygulayamayacağı ve cezayı kendisine infaz edecek bir üst merci de bulunmadığı için infaz imkânı ortadan kalkmaktadır. Kul haklarını ilgilendiren cezalarda ise infâz yetkisi hak sahibine ait olduğu için devlet başkanı da bu cezalara muhatap olma hususunda başkaları gibi görülmektedir. ${ }^{64}$

Abdülkâdir Ûdeh, Hanefîlerin bu görüşüne karşılık Şâfi'î, Mâlikî ve Hanbelîlerden oluşan cumhurunun yaklaşımına göre, suç ve cezalar arasında herhangi bir ayırım yapılmaksızın devlet başkanının da cezaya muhatap olduğunu belirtmektedir. Çünkü konuyla ilgili naslar umûm ifade etmekte ve işlenen suçlar devlet başkanı dâhil herkes için yasaklanmış bulunmaktadır. Ayrıca ceza infaz yetkisi yalnızca devlet başkanına ait değil ona ve onun temsilcisi durumundaki mercilere aittir. Dolayısıyla devlet başkanı da bir suç işlediğinde ve mahkeme cezaya hükmettiğinde yetkili merciler bu cezayı infâz ederler. ${ }^{65}$

Hanefîlerin devlet başkanına had cezasının uygulanmayacağına dair yaklaşımları öne sürdükleri gerekçeden de anlaşıldığı üzere, devlet başkanını kayırıcı bir anlayıştan ileri gelmemekte, devlet başkanına ceza infazının pratikteki zorluğunun göz önünde bulundurulmasından kaynaklanmaktadır. Bu yaklaşımda o dönemin devlet sisteminin de önemli bir etkiye sahip olduğunu söyleyebiliriz. Ancak konuyla ilgili makalesinde Yaşar Yiğit'in de ifade ettiği gibi bu yaklaşımın dayandığı gerekçeler günümüz devlet mekanizması ve anlayışı açısından geçerliliğini yitirmiş durumdadır. ${ }^{66}$ Ayrıca yukarıda aktardığımız hadiste ${ }^{67}$ hırsızlık yapan bir kadınla ilgili olarak ortaya konan prensip ve Hz. Peygamber ile râşid halifelerin bu prensibi destekleyici mahiyetteki uygulamaları ${ }^{68}$ da bizde bu yaklaşımın isabetli olmadığı kanaatini oluşturmaktadır.

\section{Ceza İnfâz Edilirken Gözetilmesi Gereken Esaslar}

Gerek Hz. Peygamber'in (s.a.v.) söz ve uygulamaları gerekse fıkhî kaynaklarda yer alan İslam hukukçularının ceza infazına dair görüş ve ictihâdları, İslam ceza hukukunda cezanın infazı sırasında da riayet edilmesi gereken bir takım ilke ve esasların bulunduğunu göstermektedir. İslam hukukunda cezalandırmanın

63 Merğînânî, el-Hidâye, thk. Tallâl Yusuf, 2/349; Ûdeh, et-Teşrîu'I-cinâî, 1/320; Yiğit, "Eşitlik İlkesi ve Dokunulmazlık", 202.

64 Merğînânî, el-Hidâye, thk. Tallâl Yusuf, 2/349; İbnü'l-Hümâm, Fethu'I-Kadîr, 5/277; Ûdeh, et-Teşrîu'l-cinâî, 1/321; Yiğit, "Eşitlik Illkesi ve Dokunulmazlık", 202.

65 Ûdeh, et-Teşrîu'I-cinâî, 1/322-323; Yiğit, “Eşitlik İlkesi ve Dokunulmazlık”, 203.

66 Yiğit, "Eşitlik Illkesi ve Dokunulmazlık", 203.

67 bk. s. 13-14.

68 Bu uygulamalarla ilgili örnekler için bkz. Ûdeh, et-Teşrîu'l-cinâî, 317-320; Yiğit, "Eşitlik Illkesi ve Dokunulmazlık", 199-202. 
amacı, suçludan intikam almak ve ona azap çektirmek değil, suçluyu ıslah etmek ve suçu önlemektir. ${ }^{69}$ Suçu sabit olan kimseye gerekli ceza infaz edilirken bu amaca uygun hareket edilmeli, ölçüyü aşacak tavır ve hareketlerden kaçınılmalı, suçlunun da hukuku gözetilmelidir. Bu ana başlıkta İslam hukukuna göre ceza infaz edilirken riayet edilmesi gereken belli başlı esasları ele alacağız.

\subsection{Suçluya İşkence Edilmemesi}

İslam hukukundaki ceza infaz sistemini incelediğimizde, cezaların tatbikinde mutedil bir ölçünün benimsendiği, cezanın gayesine aykırı bir şekilde suçluya işkence sayılabilecek uygulamalarda bulunmaktan kaçınıldığı açık bir şekilde görülmektedir. Bu durumu gösteren örneklerden birisi, aynı mahiyetteki suçların tekerrürü halinde suçluya uygulanan ceza infaz biçimidir. Bununla ilgili Kâsânî́nin şu ifadelerini aktarmakta fayda görüyoruz:

“Bir kimse defalarca zina, şarap içme ya da sarhoş olma suçunu işlese, bu kimseye yalnızca tek bir had cezası uygulanması gerekir. Çünkü had cezasını uygulamaktan maksat suçu önlemektir. Bu maksat ise tek bir had cezası ile hâsıl olur... Bir kimse zina, içki içme, sarhoş olma ya da hırsızlık suçunu işler de kendisine had uygulanır, sonra tekrar bu suçlardan birini işlerse kendisine ikinci kez had uygulanır. Çünkü bu durumda maksadın hâsıl olmadığı ortaya çıkmıştır."70

Bu açıklama, İslam ceza hukukunda cezaların suçluya acı çektirme ve işkence etme amacı taşımadığını, aksine suçluyu ıslah amaç taşıdığını ortaya koymaktadir.

İslam hukukçuları ceza uygulanırken suçlunun güvenlik ve sağlığını koruyucu tedbirlerden dahi söz etmişlerdir. Bu bağlamda zina eden bekâr kimseler için celde (kırbaç) cezasına ilave olarak uygulanması öngörülen sürgün cezasıyla ilgili olarak; sürgüne gönderilen suçlunun gerek yolda gerekse sürgün edildiği yerde güvenliğinin sağlanması, bulaşıcı salgın hastalık bulunan bir yere sürgün edilmemesi gibi şartlar getirilmiştir. ${ }^{71}$ Buna göre suçluların linç vb. can güvenliğini tehdit eden saldırılardan korunmasının, sağlık sorunu yaşadıklarında kendilerine tedavi imkânının sağlanmasının, İslam ceza hukukunun prensipleri açısından riayet edilmesi gereken tedbirler olduğunu söyleyebiliriz.

Cezaların infazında ölçülü hareket edilmesi; suçlunun -ölüm cezası haricindeölümüne veya ağır şekilde yaralanmasına, sakat kalmasına, temel ihtiyaçlarını karşılayamayacak hale gelmesine yol açabilecek aşırılıklara izin verilmemesi, yine İslam hukuku ceza infaz sisteminin göze çarpan özelliklerindendir. Suçluya,

69 Fadime Aktaş, İslam Hukukunda Cezaların Insan Onuru Üzerindeki Etkileri (Tokat: Tokat Gaziosmanpaşa Üniversitesi, Lisansüstü Eğitim Enstitüsü, Yüksek Lisans Tezi, 2019), 50.

70 Kâsânî, Bedâiu's-sanâi, 7/56.

71 Şemsüddîn Ebû Abdillâh Muhammed b. Ahmed er-Remlî, Nihâyetü'I-muhtâc ilâ şerhi'I-Minhâc (Beyrut: Dâru'lFikr, 1404/1984), 7/428. 
hastalık durumunda, ${ }^{72}$ aşırı soğuk ve sıcak havalarda, ${ }^{73}$ hayız ve nifas hallerinde celde cezasının uygulanmayıp ertelenmesi bu kabilden örneklerdir. ${ }^{74}$ Fıkıh kaynaklarında celde ${ }^{75}$ cezasının nasıl uygulanacağı da ayrıntılı bir şekilde tarif edilmiştir. Buna göre suçluya, yaralayıcı olmayacak şekilde, orta büyüklükte ve demiri olmayan bir kamçıyla, ${ }^{76}$ orta şiddette vurulur. ${ }^{77}$ Ayrıca baş, yüz ve tenasül uzvu gibi organlarına vurulmaz. ${ }^{78}$ Çünkü bu uzuvlara vurulması kişinin ölümüne veya bu uzuvlarını kaybetmesine sebep olabilmektedir. ${ }^{79}$ Öte yandan ceza infaz edilirken bütün vuruşlar tek bir uzva yapılmayıp, uzuvlara dağıtılır. Fakihler buna gerekçe olarak: "Çünkü bütün vuruşları tek bir uzva yapmak, o uzvun telef olmasına yol açabilir. Hâlbuki had cezası telef edici değil caydırıcı özellikte bir cezadır" demiş̧lerdir. ${ }^{80}$ Yine orta şiddetteki vuruş tanımlanırken: "telef edici olan ile acı vermeyen arasında bir vuruş" olarak ifade edilir. Çünkü cezanın maksadı telef etmeksizin suçluyu suçtan vazgeçirmeyi sağlamaktır. ${ }^{81}$

Aynı yaklaşım hırsızlık suçunun cezasının infazında da görülmektedir. İslam hukukçuları, hırsızlık yapan kişinin sağ elinin bilekten kesildikten sonra dağlanması, bu suretle akan kanın durdurulması gerektiğini ifade etmişlerdir. Çünkü aksi takdirde hırsızın kan kaybından hayatını kaybetme riski vardır. ${ }^{82}$ Yine hırsızlık yapan kişinin sol eli kesik veya sakat ise el kesme cezası infaz edilmemektedir. Çünkü bu durumda cezanın uygulanması suçluyu iki elden yoksun bırakır ki, suçlu hayatını idame ettirmesini bu denli zorlaştıracak bir duruma düşürülmez. ${ }^{83}$

Öte yandan Hz. Peygamber (s.a.v.) savaşta düşmana dahi işkence edilmesini yasaklamıştır. İlgili hadiste şöyle geçmektedir: “...Düşmanla savaşın ama antlaş-

72 Mevsılî, el-Muhtâr, thk. Beşşâr Bekrî Arâbî, 2/305-306; Muhammed b. Ahmed ed-Desûkî, Hâşiye'ale'ş-Şerhi'I-kebîr (b.y.: Dâru'l-Fikr, ts.), 4/322; Nevevî, Minhâc, thk. İvaz Kasım Ahmed İvaz, 296.

73 Ebü'l-Berekât Ahmed b. Muhammed ed-Derdîr, eş-Şerhu'l-kebîr (Desûkî'nin hâş̧iyesiyle birlikte) (b.y., Dâru'l-Fikr, ts.), 4/322; Nevevî, Minhâc, thk. İvaz Kasım Ahmed İvaz, 296.

74 Mevsılî, el-Muhtâr, thk. Beşşâr Bekrî Arâbî, 2/305-306; Derdîr, eş-Şerhu'l-kebîr, 4/322; Desûkî, Hâşiyetü'd-Desûkî, $4 / 322$.

75 Genellikle değnek veya kamçı olarak ifade edilen celde kelimesinin esasen kamçı anlamına geldiği, değnek şeklinde çevrilmesinin galat-ı meşhur olduğu yönündeki tespit için bk. Mustafa Özgür, "İslam Ceza Hukukunda Celde Cezasının İnfazında Kullanılacak Alet ve Uygulanışı Üzerine Bir İnceleme", Amasya Illahiyat Dergisi, 12 (Haziran 2019), 409-442.

76 Şihâbüddîn Muhammed b. Abdillâh et-Timurtâşî, Tenvîru'l-ebsâr ve câmiu'l-bihâr (ed-Dürrü'l-muhtâr şerhiyle birlikte), thk. Abdülmün'im Halil İbrahim (b.y.: Dâru'l-Kütübi'l-IImiyye, 1423/2002), s. 307; Buhûtî, Keşşâü'l-kınâ, $6 / 80$.

77 Timurtâşî, Tenvîru'l-ebsâr, thk. Abdülmün'im Halil İbrahim, 307; Kudûrî, Muhtasar, thk. Kâmil Muhammed Muhammed Uveyza, 195; Mevsılî, el-Muhtâr, thk. Beşşâr Bekrî Arâbî, 2/303.

78 Ebu'l-Hasen Burhâneddîn Ali b. Ebû Bekir el-Merğînânî, Bidâyetü'l-mübtedî (Kahire: Matbaatü Muhammed Ali Subh, ts.), 105; Kudûrî, Muhtasar, thk. Kâmil Muhammed Muhammed Uveyza, 195; Mevsılî, el-Muhtâr, thk. Beşşâr Bekrî Arâbî, 2/303.

79 Mevsılî, el-ihtiyâr, thk. Beşşâr Bekrî Arâbî, 2/303; Merğînânî, el-Hidâye, thk. Tallâl Yusuf, 2/341.

80 Merğînânî, el-Hidâye, thk. Tallâl Yusuf, 2/341; İbn Nüceym, el-Bahr, 5/10.

81 Mevsılî, el-ihtiyâr, thk. Beşşâr Bekrî Arâbî, 2/303; Merğînânî, el-Hidâye, thk. Tallâl Yusuf, 2/341; İbn Nüceym, , elBahr, 5/10.

82 Mevsılî, el-ihtiyâr, thk. Beşşâr Bekrî Arâbî, 2/333; Şirbînî, Muğni'l-muhtâc, 5/494; Desûkî, Hâşiyetü'd-Desûkî, 4/332; Buhûtî, Keşşâfü'l-kınâ,' 6/146-147.

83 Mevsılî, el-îhtiyâr, thk. Beşşâr Bekrî Arâbî, 2/334; Ebü'n-Necâ Şerefüddîn Musa b. Ahmed el-Haccâvî, el-iknâ' litâlibi'l-intifâ', thk. Abdüllatif Muhammed Musa es-Sübkî (Beyrut: Dâru'l-Ma'rife, ts.), 4/286. 
mayı bozmayın. Ganimete hıyanet etmeyin. Düşmana uzuvlarını kesmek suretiyle işkence etmeyin, hiçbir çocuğu öldürmeyin. "\$84 Bütün bunlar İslam ceza hukukunda işkence ve aşırılığa yer olmadığını net olarak göstermektedir.

Suçluya işkence edilmemesi ilkesiyle doğrudan irtibatlı olan bir husus da, cezanın hangi aletle infaz edileceği meselesidir. Hz. Peygamber'in (s.a.v.): "Şüphesiz Allah, iyilik yapmayı her şey hakkında farz kılmıştır. O halde öldüreceğiniz zaman bile güzel bir şekilde öldürünüz..."155 şeklindeki beyanı, İslam hukukunda cezanın suçlunun en az acı çekeceği yöntemle infâz edilmesinin temel bir prensip olduğunu göstermektedir. ${ }^{86}$ Bunun için İslam ceza hukukunda ölüm cezalarının infazında, infazın hızlı ve suçlunun daha az acı çekeceği şekilde gerçekleşmesini sağlayan kılıcın kullanımı öne çıkmıştır. ${ }^{87}$ Nitekim Hz. Peygamber (s.a.v.) de: "Kısas cezası yalnızca kılıçla infaz edilir"88 buyurmuştur.

Bu hadisi bir önceki hadisle birlikte düşündüğümüzde, ölüm cezalarının kılıçla infaz edilmesinin taabbudî bir hüküm olmadığını, kılıcın o zamanın şartlarında daha hızlı ve daha az acıyla ölümü sağlayan bir alet olması sebebiyle tercih edildiğini söyleyebiliriz. Nitekim kılıçtan kastın özellikle bu alet olmadığı, bununla öldürücü silahın kastedildiği fıkıh kaynaklarında da dile getirilmiştir. ${ }^{89}$ Dolayısıyla infazı kılıçtan daha hızlı ve daha az acı çektirerek gerçekleştirecek modern infaz yöntemlerin ölüm cezalarında kullanılmasında İslam hukuku açısından bir engel bulunmamaktadır. ${ }^{90}$ Hatta bunun İslam ceza hukukunun ilkeleri açısından daha uygun olacağını söyleyebiliriz.

Suçluya işkence ve kötü muamele yapılmaması ilkesi modern hukukta da temel bir ilke olarak kabul edilmektedir. Bu bağlamda T.C. Anayasasında işkence ve kötü muamele yasağı düzenlenmiş bulunmaktadır. Bu konuda anayasanın 17. maddesinin 3. fıkrasında yer alan hüküm şöyledir: “Kimseye işkence ve eziyet yapılamaz; kimse insan haysiyetiyle bağdaşmayan bir cezaya veya muameleye tabi tutulamaz."

\subsection{Suçluya Yönelik Hakaret ve Küçük Düşürücü Sözlerden Kaçınılması}

Cezalar infaz edilirken suçluyu tahkir edici söz ve tavırlardan kaçınılması gerektiği, ilgili naslar ile İslam hukukçularının görüşlerinden anlaşılmaktadır. İslam hukukuna göre had veya kısas cezasıyla idam edilen suçlunun cesedi, diğer

84 Ebü'l-Hüseyn Müslim b. el-Haccâc Müslim, el-Câmiu's-sahîh, thk. Muhammed Fuâd Abdulbâkî (Beyrut: Dâru İhyâi't-Türâsi'l-Arabî, ts.), "Cihâd ve's-Siyer", 1731; Tirmizî, "Diyât", 14 (No. 1408); Ebû Dâvûd, "Cihâd", 90 (No. 2613); İbn Mâce, "Cihâd", 38 (No. 2857); Mâlik b. Enes el-Asbahî el-Yemenî, el-Muvatta', thk. Abdülvehhâb Abdüllatîf (b.y.: el-Mektebetü'l-IIlmiyye, ts.), "Cihâd", 11.

85 Müslim, “Sayd ve'z-Zebâih" 1955.

86 Mustafa Özgür, İslam Infaz Hukuku (İstanbul: Cinius Yayınları, 2020), 73.

87 Özgür, İslam Infaz Hukuku, 79-80.

88 İbn Mâce, "Diyât", 25 (No. 2667).

89 Bk. Mevsılî, el-ihtiyâr, thk. Beşşâr Bekrî Arâbî, 5/28; Serahsî, el-Mebsût, 26/122.

90 Ûdeh, et-Teşrîu'l-cinâî, 2/154. Ayr. bkz. Özgür, İslam İnfaz Hukuku, 86-88.

91 T.C. Anayasası, md. 17/3. 
ölmüş mü'minler gibi yıkanıp kefenlenmekte ve bu kimsenin cenaze namazı kılınmaktadır. ${ }^{92}$ Bu durum İslam hukukunda suçlunun müslüman toplumdan dışlanmadığını, cezasını çektikten sonra toplumun diğer fertleri gibi muamele gördüğünü göstermektedir. Ayrıca suçluya sövmek, nefret söyleminde bulunmak, beddua etmek gibi davranışlar da İslam hukukunda yasaklanmıştır. Nitekim Hz. Peygamber (s.a.v.), zina ettiği için recm cezasına çarptırılan bir suçluya cezanın infazı sırasında söven birini duyduğunda, bu davranışı yasaklamış ve şöyle söylemiş̧tir: "O öyle bir tövbe etti ki, insanlardan haraç alan birisi bu tövbeyi yapsaydı o bile bağışlanırdı. ${ }^{\prime \prime 3}$

Hz. Peygamber (s.a.v.) bir başka hadisede, içki içen bir kimseye had cezası infaz edilirken suçluya, "Allah seni rezil etsin" diye beddua eden kişiye şöyle söylemiştir: "Böyle sözler söylemeyin, ona karşı şeytana yardım etmeyin." ${ }^{\prime \prime 4} \mathrm{~Hz}$. Peygamber'in (s.a.v.) uygulamalarından buna benzer pek çok örnek vermek mümkündür. Bütün bunlardan, İslam hukukuna göre cezaların suçluyu ıslah etme, suçtan vazgeçirme, suçlunun işlediği günaha kefaret olma gibi amaç ve sonuçlara matuf olduğu anlaşılmaktadır. Dolayısıyla cezalar suçluyu aşağılama vasıtası olarak görülemez.

Esasen ayet ve hadislerde günahkâr kimselere yönelik genel yaklaşım da, suçlulara nasıl davranılması gerektiği hususunda bir ölçüye işaret etmektedir. Bu nasları incelediğimizde günahkâr kimselerin, pişmanlık duyup işledikleri günahlardan vazgeçmeye, tövbe edip Allah'a yönelmeye, Allah'ın rahmetinden ümit kesmemeye teşvik edildikleri görülmektedir. Mesela bir ayette şöyle geçmektedir: "De ki: (Allah şöyle buyuruyor): Ey kendi aleyhlerine olarak günahta haddi aşan kullarım, Allah'ın rahmetinden ümit kesmeyin. Çünkü Allah bütün günahları bağışlar. Gerçekten O, çok bağışlayıcı, çok merhametlidir. ${ }^{195} \mathrm{~Hz}$. Peygamber (s.a.v.) de şöyle söylemiştir: "Her Âdemoğlu çokça hata yapar. Çokça hata yapanların en hayırlısı ise çokça tövbe edenlerdir. ${ }^{\prime \prime 96}$ Bu gibi naslar İslam'a göre suçlu ve günahkâr kimselerin dışlanıp hor görülmemesi, aksine topluma kazandırılması gerektiğini göstermektedir. Dolayısıyla suçlulara onur kırıcı ve aşağılayıcı sözler söylemek nasların bu yaklaşımıyla da bağdaşmamaktadır. Zira bu tür tutumlar suçluyu yanlışından vazgeçirmek bir yana, onu topluma karşı daha tepkili hale getirir ve daha fazla suça iter.

\subsection{Cezanın Alenî ve Şeffaf Bir Şekilde İnfâz Edilmesi}

İslam hukukundaki ceza infaz sisteminin önemli özelliklerinden birisi de cezaların infazında aleniyet ve şeffaflığa riayet ilkesidir. Zira zina suçunun cezasından

92 Serahsî, el-Mebsût, 2/52; Şîrâzî, el-Mühezzeb, 1/251; İbn Rüşd, Bidâyetü'l-müctehid, 1/253; Haccâvî, el-iknâ', thk. Abdüllatif Muhammed Musa es-Sübkî, 1/228.

93 Müslim, "Hudûd", 1695; Ebû Dâvûd, "Hudûd", 25 (No. 4442).

94 Buhârî, "Hudûd", 5 (No. 6777); Ebû Dâvûd, "Hudûd", 36 (No. 4477).

95 ez-Zümer 39/53.

96 Tirmizî, "Sıfatü'l-kıyâme ve'r-rekâık ve'l-vera"', 49 (No. 2499.) 
bahseden ayetin sonunda bu ilkeye riayet edilmesi gerektiği şöyle ifade edilmektedir: "...Mü'minlerden bir topluluk da onlara uygulanan cezaya şahit olsun."197 Bunun için İslam hukukçuları, yetkili merci tarafından had cezasının infazı sırasında bir topluluğun hazır bulunmasının sağlanmasının uygun olacağı hususunda ittifak etmişlerdir. ${ }^{98}$ Hatta bazı İslam hukukçuları bunun vâcib olduğunu ifade etmiş̧tir. ${ }^{99}$ Öte yandan Kâsânî, bu hükmün yalnızca zina suçuna mahsus olmadığını, diğer had cezalarının infazında da geçerli olduğunu belirtmiştir. Çünkü had cezalarının hepsinden maksat toplumu suç işlemekten caydırıp alıkoymaktır. ${ }^{100}$ Hatta aynı gerekçeden dolayı had cezalarının dışında kısas ve ta'zîr cezaları için de bu hükmün geçerli olduğunu söyleyebiliriz. Nitekim çağdaş İslam hukukçularından Abdülkâdir Ûdeh de, İslam hukukunda asıl olanın infazın aleni şekilde uygulanması olduğunu ifade etmiştir. ${ }^{101}$

Ceza infazının alenî olmasının iki temel amacı bulunmaktadır. Bunlardan birisi esasen cezanın caydırıcılığı ilkesinin uygulanmasını sağlamaktır. Zira cezanın topluluk önünde infâz edilmesi halinde, infaza şahit olanlar gördükleri manzaradan etkilenip suç işlemekten kaçınacakları gibi, orada bulunmayanlar da bulunanların bildirmesiyle infazdan haberdar olacak ve korkup benzer bir suçu işlemekten uzak duracaklardır. ${ }^{102}$ Cezanın aleniliğinin diğer amacı ise, cezanın infazı sırasında takdir edilen ölçünün aşılıp suçluya işkence ve kötü muamele yapılmasının önüne geçmektir. ${ }^{103}$

İslam hukukçuları infâzın aleniliğinin ölçüsünü tespitte muhtelif görüşler ortaya koymuşlardır. İbn Abbâs ve Mücâhid b. Cebr'in (öl. 103/721), infâzı gerçekleştirecek kişinin dışında cezaya bir kişinin bile şahit olmasının yeterli olacağı görüşünde oldukları nakledilmiştir. Hanbelî fakihler de bu kanaattedirler. ${ }^{104}$ Atâ b. Ebî Rebâh (öl. 114/732) ve İshak b. Râhûye (öl. 238/853) en az iki kişinin, Zührî (öl. 124/742) üç kişinin, Hasan-ı Basrî (öl. 110/728) ise on kişinin infâz sırasında hazır bulunması gerektiğini söylemişlerdir. ${ }^{105}$ Şâfi'î ve Mâlikî fakihler en az dört kişiyi şart görmüşlerdir. ${ }^{106}$ Cessâs (öl. 370/981) ise infâzın topluluk önünde yapıl-

97 en-Nûr 24/2

98 İbn Rüşd, Bidâyetü'I-müctehid, 4/221. Ayr. bk. Kâsânî, Bedâiu's-sanâi', 7/60; Nevevî, Ravza, thk. Züheyr eş-Şâvîş, $10 / 99$.

99 Ebû Abdillâh Şemsüddîn Muhammed b. Muhammed el-Hattâb er-Ruaynî, Mevâhibü'l-Celîl li-şerhi Muhtasari Halîl (b.y.: Dâru'l-Fikr, 1412/1992), 6/295; Takiyyüddîn Muhammed b. Ahmed el-Fütûhî, Müntehe'l-irâdât, thk. Abdullah b. Abdülmuhsin et-Türkî (b.y.: Müessesetü'r-Risâle, 1419/1999), 5/117.

100 Kâsânî, Bedâiu's-sanâi,' 7/60.

101 Ûdeh, et-Teşrîu'l-cinâî, 1/764.

102 Kâsânî, Bedâiu's-sanâi', 7/60-61; Ebû Bekr Ahmed b. Ali el-Cessâs, Ahkâmü'l-Kur'ân, thk. Abdüsselâm Muhammed Ali Şâhîn (Beyrut: Dâru'l-Kütübi'l-Ilmiyye, 1415/1994), 3/344.

103 Kâsânî, Bedâiu's-sanâi', 7/61.

104 İbnü'l-Hümâm, Fethu'I-Kadîr, 5/234; İbn Kudâme, el-Muğnî, 9/45; Fütûhî, Müntehe'l-irâdât, thk. Abdullah b. Abdülmuhsin et-Türkî, 5/117.

105 İbnü'l-Hümâm, Fethu'I-Kadîr, 5/234; İbn Rüşd, Bidâyetü'l-müctehid, 4/221; Hattâb, Mevâhibü'l-Celîl, 6/295; İbn Kudâme, el-Muğnî, 9/45; Cessâs, Ahkâmü'l-Kur'ân, thk. Abdüsselâm Muhammed Ali Şâhîn, 3/344.

106 İbnü'l-Hümâm, Fethu'I-Kadîr, 5/234; Şirbînî, Muğni'l-muhtâc, 5/455; Nevevî, Ravza, thk. Züheyr eş-Şâvîş, 10/99; İbn Rüşd, Bidâyetü'l-müctehid, 4/221; Hattâb, Mevâhibü'l-Celîl, 6/295; İbn Kudâme, el-Muğnî, 9/45; Cessâs, Ahkâmü'l-Kur'ân, thk. Abdüsselâm Muhammed Ali Şâhîn, 3/344. 
masının cezanın caydırıcılığını sağlama gerekçesine dayanmasından yola çıkarak, esas olanın infaz sırasında infâz haberinin yayılmasına vesile olacak kadar kimsenin bulunması olduğunu belirtmiş, belli bir sayı sınırlaması yapmamıştır. ${ }^{107}$

Mustafa Özgür, konuyla ilgili makalesinde gerek müfessirlerin infazın aleniliğine dayanak teşkil eden ayete getirdikleri yorumlardan, gerekse Cessâs'ın yaklaşımından yola çıkarak, alenilik ile teşhircilik arasındaki farka işaret etmekte ve cezanın infazı bağlamında iki kavramı birbirinden ayırmanın önemine dikkat çekmektedir. Buna göre infâzın aleniliğinden maksat suçlunun onurunun kırılıp toplum önünde küçük düşürülmesi değildir. Bundan maksat hem suçluyu infaz sırasında ölçüyü aşan tutumlardan korumak, hem de toplumun ibret almasını ve benzer suçları işlemekten kaçınmasını sağlamaktır. Bunun için cezanın bu maksadın hâsıl olacağı kadar topluluk huzurunda infâz edilmesi yeterli olup, suçlunun teşhir edilip onur ve haysiyetinin kırılması doğru değildir. ${ }^{108}$

Kanaatimizce bu yaklaşım, makalede ele alınan İslam hukukunun cezalandırmada gözettiği ilke ve esaslarla örtüşmektedir. Bu sebeple biz de bu kanaate katılıyoruz. Bununla birlikte aleniliğin sağlanması için gereken infaz yöntemlerinin içinde bulunulan dönemin şartlarına göre farklılık arz edeceğini de belirtmeliyiz. Zira geçmiş dönemlerde küçük topluluklarda uygulanan infaz yöntemlerinin, günümüzün toplumsal koşullarında aynı sonuçlara ulaştırmayacağı açıktır. Bu sebeple cezalarda alenilik ilkesinin ne şekilde uygulanacağı tespit edilirken yaşanan çağın şartlarının ve imkânlarının da dikkate alınması gerektiğini söyleyebiliriz.

Cezanın aleniliği bağlamında temas etmekte fayda gördüğümüz bir husus da, işlenen suçun şahitlerinin ve mağdurun infaz sırasında hazır bulunması meselesidir. Hanefî fakihler özellikle recm cezasında -suç şahitlerin tanıklığıyla sabit olmuşsa- şahitlerin infaz sırasında hazır bulunmasını şart görmüşlerdir. Aksi takdirde ceza düşmektedir. ${ }^{109}$ Hanefîlerin bu yaklaşımında, şahitlerin güvenilirliği hususunda yanılgıya düşülmüş olma ihtimalinin dikkate alındığını ve böyle bir durum varsa infaz sırasında hazır bulunan şahitlerin şahitliklerinden rücu etmelerinin kuvvetle muhtemel olduğunun düşünüldüğünü, bu suretle recm gibi ağır bir cezanın masum bir insana uygulanmasının önüne geçilmesinin amaçlandığını söyleyebiliriz.

Fıkıh kaynaklarında, mağdurun af yetkisinin olduğu kısas cezası başta olmak üzere, kul hakkı ihlali içeren suçların cezaları infaz edilirken mağdur veya mağdur yakınlarının hazı bulunması şartının arandığı da görülmektedir. Hanefî fakihlere göre maktulün kısasa karar verme ehliyetine sahip bulunan yakınlarının tamamının kısas infaz edilirken hazır bulunması şarttır. Çünkü cezanın infazından önce

107 Cessâs, Ahkâmü'l-Kur'ân, thk. Abdüsselâm Muhammed Ali Şâhîn, 3/344.

108 Özgür, "İnfazın Temel İlkeleri”, 59-62.

109 Serahsî, el-Mebsût, 9/50; Mevsılî, el-ihtiyâr, thk. Beşşâr Bekrî Arâbî, 2/302. 
katili affetme ihtimalleri bulunmaktadır. ${ }^{110}$ Yine hırsızlık suçunun cezası infaz edilirken malı çalınan kişinin hazır bulunması gerektiği Hanefî fakihlerce ifade edilmiştir. ${ }^{11}$ Buna gerekçe olarak da, bu kişinin infaz öncesi malını hırsıza hibe ettiğini veya sattığını söylemesi, böylelikle cezanın düşmesi ihtimalini göstermişlerdir. ${ }^{112}$

Bütün bunlar cezanın aleniliği ilkesinin, suçlu sanılarak masum insanlar üzerinde ceza infaz edilmesi gibi durumları önleyici bir tedbir olduğu gibi, mağdurun affetmesi vb. cezayı düşürücü hallerden birinin gerçekleşmesine imkân tanıyıcı bir işleve sahip olduğunu göstermektedir.

\section{Sonuç}

İslam hukukuna göre suçluları cezalandırmanın temel amacı suç işlenmesini önlemek suretiyle toplumun huzur ve güvenliğini sağlamanın yanında haksız fiillere gereken karşılığı vererek adaleti gerçekleştirmektir. Gerek ilgili Kur'an ayetleri ve Hz. Peygamber'in (s.a.v.) uygulaması gerekse İslam hukukçularının fıkhî kaynaklarda yer alan yaklaşımları incelendiğinde, İslam ceza hukukunun bu temel amaçları gerçekleştirmeye matuf ilke ve esaslarının olduğu görülmektedir. Bu ilke ve esaslar, hem yargılama sonucunda suçluya ceza kararı verilirken hem de takdir edilen cezanın infazı sırasında riayet edilmesi gereken prensipleri kapsamaktadır.

İslam ceza hukukuna göre suçu ispat edilmedikçe hiç kimse peşinen suçlu olarak kabul edilemez. Sanığın inancı, dünya görüşü, yaşam tarzı, sosyal konumu vb. hiçbir husus ona suçlu muamelesi yapmaya gerekçe sayılamaz. Sanık hakkında karar verilirken yalnızca delillere göre hareket edilmelidir. "Berâet-i zimmet asıldır" ilkesi olarak ifade edilen, modern hukukta "masumiyet karinesi" adıyla yer almış bulunan bu ilke, İslam ceza hukukunun temel esaslarından birisidir. Öte yandan bu ilkenin bir gereği olan ve yine modern hukukta "şüpheden sanık yararlanır" terimiyle ifade edilen prensip, İslam ceza hukukunda "şüphelerle hadlerin düşürülmesi" kaidesiyle ortaya konmuş temel bir esastır.

İslam hukuku suç-ceza dengesinin korunmasını adaleti sağlamanın temel şartlarından biri olarak görmektedir. Bu bağlamda hafif suçlara ağır cezalar verilmesi ve ağır suçlara caydırıcı olmayan hafif cezalar verilmesi adalet mefhumuna aykırı görülür. Kısas cezası ve bu cezanın tatbiki için aranan şartlar, İslam ceza hukukunda cezanın suç ile orantılı olmasının temel bir esas olarak benimsendiğini gösteren en bariz örneklerdendir. Ayrıca bu esas Kur'ân'da "misliyle cezalandırma" ifadesiyle bizzat ortaya konmaktadır.

110 Mevsılî, el-ihtiyâr, thk. Beşşâr Bekrî Arâbî, 2/454; Vehbe b. Mustafa ez-Zühaylî, el-Fıkhu'l-islâmî ve edilletühû (Dımaşk: Dâru'l-Fikr, ts.), 7/5683.

111 Kudûrî, Muhtasar, thk. Kâmil Muhammed Muhammed Uveyza, 202; Timurtâşî, Tenvîru'l-ebsâr, thk. Abdülmün'im Halil İbrahim, 326.

112 Mevsılî, el-ihtiyâr, thk. Beşşâr Bekrî Arâbî, 2/328; Merğînânî, el-Hidâye, thk. Tallâl Yusuf, 2/371; Haskefí, ed-Dürrü'lmuhtâr, thk. Abdülmün'im Halil İbrahim, 326. 
İslam ceza hukukunda masum insanların mağdur olmaması için ceza kararı verilirken ihtiyatlı ve titiz davranılması gerekli olduğu gibi, ağır insan hakkı ihlallerinde bulunan veya kamu düzenini bozan kimselerin, suçları sabit olduğunda cezalandırılmalarında tavizsiz ve kararlı bir duruş gösterilmesi de elzem görülmektedir. İslam hukuku din, can, mal, ırz ve aklı, korunması zaruri olan beş temel unsur olarak benimsemiş, bu unsurlara karşı işlenen suçlara ağır ve caydırıcı cezalar getirmiştir. Yine kamu hukukunun ihlal edildiği ağır suçlara karşılık öngörülen had cezalarında kimseye af yetkisi tanımamış, insan hayatına ve vücut bütünlüğüne karşı işlenen suçlarda ise mağdurdan başka kimseye suçluyu affetme hakkı vermemiştir. Bütün bunlar cezanın caydırıcılığı ilkesinin gereklerindendir.

Hukuk önünde kimseye ayrıcalık tanınmaması, herkesin kanunlar karşısında eşit kabul edilmesi de, İslam hukukunda adaletin sağlanması açısından taviz verilemeyecek bir esas olarak görülmektedir. Sanığın maddi durumu, sosyal konumu asla kendisine imtiyaz sağlanmasına gerekçe teşkil edemez. Hz. Peygamber'in (s.a.v.) "Fâtıma hırsızlık yapsaydı onun da elini keserdim" sözü bu esası net bir şekilde ortaya koyduğu gibi, bu esasa riayet edilmemesinin toplumsal felaketlere sebep olacağına yine Hz. Peygamber tarafından işaret edilmiştir.

İslam ceza hukukunda suçlu intikam alınacak bir düşman değil, ıslah edilmesi gereken bir toplum ferdi olarak görülür. Bu sebeple suçluya yönelik işkence, aşağılama, toplumdan dışlama gibi insan onuruyla bağdaşmayan davranışlarda bulunulması kesinlikle yasaklanmıştır. Kendisine sadece hukukun öngördüğü ceza uygulanır ve cezasını çeken suçlu toplumun diğer fertleri gibi muamele görür. Suçlunun idam edildikten sonra yıkanıp cenazesinin kılınması, infaz sırasında kendisine hakaret ve beddua edilmesinin yasaklanması, hatta çektiği cezanın günahına kefaret olduğunun belirtilmesi gibi Hz. Peygamber'in (s.a.v.) uygulama ve sözlerinde görülen tutumlar, suçlunun da hukukuna riayet edilmesi gerektiğini gösteren örneklerdir. Bunun için İslam hukukçuları, infaz sırasında riayet edilmesi gereken, cezanın işkenceye dönüşmesini önleyici ve suçlunun haysiyetini koruyucu birçok şarttan söz etmişlerdir.

İnfazın alenî bir şekilde gerçekleştirilmesi, hem takdir edilen cezayı aşıp suçluya kötü muamelede bulunulmasına engel olucu, hem de infazın topluma duyurulması suretiyle cezadan amaçlanan caydırıcılığı sağlayıcı bir fonksiyona sahiptir. Bu sebeple İslam ceza hukukunda cezanın aleni ve şeffaf bir şekilde infaz edilmesi temel bir esas olarak benimsenmiştir. Ancak infazın aleni olmasından maksat suçlunun teşhir edilip toplum önünde küçük düşürülmesi değil, toplumun infazdan haberdar edilerek cezanın caydırıcılığını temin etmektir. Bundan dolayı İslam hukukçuları cezanın infazı sırasında bu amacın gerçekleşeceği kadar kişinin hazır bulunmasının yeterli olacağını belirtmişlerdir. Bu açıdan infazın kalabalık topluluklar huzurunda yapılması, kameraya çekilip görüntülerinin medya yoluyla toplumla paylaşılması gibi uygulamalar, kanaatimizce İslam ceza hukukunun ilke ve amaçlarıyla bağdaşmamaktadır. 


\section{Kaynakça}

Akşit, Mustafa Cevat. İslam Ceza Hukukunda Insanî Esaslar Üzerine Bir Deneme. Erzurum: Atatürk Üniversitesi, Sosyal Bilimler Enstitüsü, Doktora Tezi, 1975.

Aktaş, Fadime. İslam Hukukunda Cezaların Insan Onuru Üzerindeki Etkileri. Tokat: Tokat Gaziosmanpaşa Üniversitesi, Lisansüstü Eğitim Enstitüsü, Yüksek Lisans Tezi, 2019.

Ali Haydar Efendi. Düreru'l-hükkâm şerhu Mecelleti'l-ahkâm. 4 Cilt. b.y.: Dâru'I-Cîl, $1411 / 1991$.

Asbahî, Mâlik b. Enes el-Yemenî. el-Muvatta'. thk. Abdülvehhâb Abdüllatîf. b.y.: elMektebetü'l-illmiyye, ts.

Bardakoğlu, Ali. "Ceza”. Türkiye Diyanet Vakfı İslam Ansiklopedisi. 7/470-478. İstanbul: TDV Yayınları, 1993.

Behnesî, Ahmed Fethî. Medhalü'l-fıkhi'l-cinâiyyi'Iİslâmî. Beyrut: Dâru'ş-Şurûk, 4. Basım, 1409/1989.

Buhârî, Ebû Abdillâh Muhammed b. İsmâil. el-Câmiu's-Sahîh. thk. Muhammed Züheyr b. Nâsır en-Nâsır. 9 Cilt. Beyrut: Dâru Tavkı'n-Necât, 1422/2001.

Buhûtî, Mansûr b. Yunus. Keşşâfü'I-kınâ' 'an metni'I-iknâ'. 6 Cilt. b.y.: Dâru'I-Kütübi'I-IImiyye, ts.

Cessâs, Ebû Bekr Ahmed b. Ali. Ahkâmü'l-Kur'ân. thk. Abdüsselâm Muhammed Ali Şâhîn. 3 Cilt. Beyrut: Dâru'l-Kütübi'l-Ilmiyye, 1415/1994.

Çatlı, Tugay. Yargı Kararları Işı̆ında Ceza Muhakemesinde Masumiyet Karinesi. Antalya: Antalya Bilim Üniversitesi, Lisansüstü Eğitim Enstitüsü, Yüksek Lisans Tezi, 2020.

Çiçek, Mustafa. Kısa Süreli Hapis Cezalarına Seçenek Olarak Sunulan Yaptırımların Değerlendirilmesi. İstanbul: İstanbul Üniversitesi, Adli Tıp Enstitüsü, Yüksek Lisans Tezi, 2019.

Çiçek, Safetullah. İslam Ceza Hukukunda Şüphe Kavramı ve Cezalara Etkisi. Van: Yüzüncü Yıl Üniversitesi, Sosyal Bilimler Enstitüsü, Yüksek Lisans Tezi, 2009.

Derdîr, Ebü'l-Berekât Ahmed b. Muhammed. eş-Şerhu'l-kebîr. 4 Cilt. b.y.: Dâru'l-Fikr, ts.

Desûkî, Muhammed b. Ahmed. Hâşiye 'ale'ş-Şerhi'l-kebîr. 4 Cilt. b.y.: Dâru'l-Fikr, ts.

Ebû Dâvûd, Süleyman b. el-Eş'as es-Sicistânî. Sünen-i Ebî Dâvûd. thk. Şuayb el-ArnaûtMuhammed Kâmil Karabelli. 7 Cilt. b.y.: Dâru'r-Risâleti'l-Âlemiyye, 1430/2009.

Ebû Zehre, Muhammed. el-Cerîme ve'l-ukûbe fi'l-fikhi'l-Islâmî. Kahire: Dâru'l-Fikri'l-Arabî, 1998.

Erdoğan, Mehmet. Fıkıh ve Hukuk Terimleri Sözlüğü. İstanbul: Ensar Neşriyat, 3. Basım, 2010.

Fütûhî, Takiyyüddîn Muhammed b. Ahmed. Müntehe'l-irâdât. thk. Abdullah b. Abdülmuhsin et-Türkî. 5 Cilt. b.y.: Müessesetü'r-Risâle, 1419/1999.

Haccâvî, Ebü'n-Necâ Şerefüddîn Musa b. Ahmed. el-iknâ' li-tâlibi'l-intifâ'. thk. Abdüllatif Muhammed Musa es-Sübkî. 4 Cilt. Beyrut: Dâru'l-Ma'rife, ts.

Haddâd, Ebû Bekr b. Ali. el-Cevheretü'n-neyyire. 2 Cilt. b.y.: el-Matbaatü'l-Hayriyye, 1322/1904.

Haskefî, Muhammed b. Ali Alâüddîn. ed-Dürrü'l-muhtâr şerhu Tenvîri'l-ebsâr ve câmi'i'lbihâr. thk. Abdülmün'im Halil İbrahim. b.y.: Dâru'I-Kütübi'I-IImiyye, 1423/2002.

Hattâb, Ebû Abdillâh Şemsüddîn Muhammed b. Muhammed er-Ruaynî. Mevâhibü'l-Celîl Ii-şerhi Muhtasari Halîl. 6 Cilt. b.y.: Dâru'l-Fikr, 3. Basım, 1412/1992. 
İbn Âbidîn, Muhammed Emîn b. Ömer. Reddü'l-muhtâr 'ale'd-Dürri'l-muhtâr. 6 Cilt. Beyrut: Dâru'l-Fikr, 2. Basım, 1412/1992.

İbn Kayyim, Ebû Abdillâh Muhammed b. Ebî Bekr el-Cevziyye. I'lâmü'l-muvakkiîn an Rabbi'l-âlemîn. 7 Cilt. Suudi Arabistan: Dâru İbni'l-Cevzî, 1423/2002.

İbn Kudâme, Muvaffakuddîn. el-Muğnî. 10 Cilt. b.y.: Mektebetü'I-Kahire, 1388/1968.

İbn Mâce, Ebû Abdillâh Muhammed b. Yezîd el-Kazvînî. Sünen-i ibn Mâce. thk. Şuayb elArnaût vd. 5 Cilt. Beyrut: Dâru'r-Risâleti'l-Âlemiyye, 1430/2009.

İbn Nüceym, Zeynüddîn b. İbrahim el-Mısrî. el-Bahru'r-râik. 8 Cilt. b.y.: Dâru'I-Kitâbi'I-İslâmî, 2. Basım, ts.

İbn Rüşd, Ebu'l-Velîd Muhammed b. Ahmed. Bidâyetü'l-müctehid ve nihâyetü'l-muktesıd. 4 Cilt. Kahire: Dâru'l-Hadîs, 1425/2004.

İbnü'l-Arabî, Muhammed b. Abdullah Ebû Bekr. Ahkâmü'l-Kur'ân. 4 Cilt. Beyrut: Dâru'lKütübi'l-IImiyye, 3. Basım, 1424/2003.

İbnü'l-Hümâm, Kemâlüddîn Muhammed b. Abdülvâhid. Fethu'I-Kadîr. 10 Cilt. b.y.: Dâru'IFikr, ts.

Kal'acî, Muhammed Revvâs - Kanîbî, Hâmid Sâdık. Mu'cemu luğati'l-fukahâ. b.y.: Dâru'nNefâis, 1408/1988.

Kâsânî, Alâüddîn Ebû Bekr b. Mes'ûd. Bedâiu's-sanâi' fî tertîbi'ş-şerâi'. 7 Cilt. b.y.: Dâru'lkütübi'l-ilmiyye, 2. Basım, 1406/1986.

Kaya, Eyyüp Said - Hacak, Hasan. "Zimmet". Türkiye Diyanet Vakfı İlam Ansiklopedisi. 44/424-428. İstanbul: TDV Yayınları, 2013.

Kudûrî, Ahmed b. Muhammed Ebü'l-Hüseyn. Muhtasaru'I-Kudûrî. thk. Kâmil Muhammed Muhammed Uveyza. b.y.: Dâru'I-Kütübi'l-IImiyye, 1418/1997.

Memiş, Pınar. Adil Yargılanma Hakkının Unsuru Olarak Masumiyet Karinesi. İstanbul: Galatasaray Üniversitesi, Sosyal Bilimler Enstitüsü, Yüksek Lisans Tezi, İstanbul, 2003.

Merğînânî, Ebu'I-Hasen Burhâneddîn Ali b. Ebû Bekir. Bidâyetü'I-mübtedî. Kahire: Matbaatü Muhammed Ali Subh, ts.

Merğînânî, Ebu'l-Hasen Burhâneddîn Ali b. Ebû Bekir. el-Hidâye. thk. Tallâl Yusuf. 4 Cilt. Beyrut: Dâru Ihyâi't-Türâsi'l-Arabî, ts.

Mevsılî, Abdullah b. Mahmud. el-ihtiyâr li ta'lîli'l-Muhtâr. thk. Beşşâr Bekrî Arâbî. 2 Cilt. Dımaşk: Dâru'l-Kubâ, ts.

Mevsılî, Abdullah b. Mahmud. el-Muhtâr li'l-fetvâ. thk. Beşşâr Bekrî Arâbî. 2 Cilt. Dımaşk: Dâru'l-Kubâ, ts.

Molla Hüsrev, Muhammed b. Ferâmerz. Dürerü'l-hükkâm şerhu Ğureri'l-ahkâm. 2 Cilt. b.y.: Dâru İhyâi'l-Kütübi'l-Arabiyye, ts.

Molla Hüsrev, Muhammed b. Ferâmerz. Mir'âtü'l-usûl 'alâ Mirkâti'l-vusûl. İstanbul: Eser Kitabevi, ts.

Müslim, Ebu'I-Hasen Müslim b. Haccâc en-Nîsâbûrî. es-Sahîh. thk. Muhammed Fuâd Abdulbâkî. 5 Cilt. Beyrut: Dâru İhyâi't-Türâsi'l-Arabî, ts.

Nevevî, Ebû Zekeriyyâ Muhyiddîn Yahya b. Şeref. Minhâcü't-tâlibîn ve umdetü'I-müftîn. thk. İvaz Kasım Ahmed İvaz. b.y.: Dâru'l-Fikr, 1425/2005.

Nevevî, Ebû Zekeriyyâ Muhyiddîn Yahya b. Şeref. Ravzatü't-tâlibîn ve umdetü'l-müftîn. thk. Züheyr eş-Şâvîş. 12 Cilt. Beyrut: el-Mektebü'l-islâmî, 3. Basım, 1412/1991. 
Özay, Hilal. İslâm Ceza Hukukunun Temel Prensipleri. Ankara: İksad Yayınevi, 2019.

Özgür, Mustafa. "İslam Ceza Hukukunda Celde Cezasının İnfazında Kullanılacak Alet ve Uygulanışı Üzerine Bir İnceleme". Amasya Ilahiyat Dergisi, 12 (Haziran 2019), 409-442.

Özgür, Mustafa. "İslam Ceza Hukukunda İnfazın Temel İlkeleri". Artvin Çoruh Üniversitesi Illahiyat Araştırmaları Dergisi 3/1 (2019), 53-78.

Özgür, Mustafa. İslam Infaz Hukuku. İstanbul: Cinius Yayınları, 2020.

Polat, Murat. "İslâm Ceza Hukukunun Karakteristik Özelliklerinden Bazı Örnekler". Amasya Üniversitesi Illahiyat Fakültesi Dergisi 9 (2017), 249-286.

Polat, Murat. İslam Ceza Hukukunda Suç ve Ceza Arasındaki Denge. Erzurum: Atatürk Üniversitesi, Sosyal Bilimler Enstitüsü, Doktora Tezi, 2015.

Remlî, Şemsüddîn Ebû Abdillâh Muhammed b. Ahmed. Nihâyetü'l-muhtâc ilâ şerhi'lMinhâc. 8 Cilt. Beyrut: Dâru'l-Fikr, 1404/1984.

Serahsî, Muhammed b. Ahmed Şemsüleimme. el-Mebsût. 30 Cilt. Beyrut: Dâru'l-Ma'rife, 1414/1993.

Şîrâzî, Ebû İshâk İbrahim b. Ali. el-Mühezzeb fî fıkhi'l-Imâm eş-Şâfi'î. 3 Cilt. b.y.: Dâru'lKütübi'l-ilmiyye, ts.

Şirbînî, Şemsüddîn Muhammed b. Ahmed el-Hatîb. Muğni'l-muhtâc ilâ ma'rifeti meânî elfâzi'l-Minhâc. 6 Cilt. b.y.: Dâru'l-Kütübi'I-IImiyye, 1415/1994.

TCK, Türk Ceza Kanunu (Kanun No. 5237). Resmî Gazete 25611 (26 Eylül 2004). Erişim 7 Ekim 2021. https://www.mevzuat.gov.tr/MevzuatMetin/1.5.5237.pdf

Timurtâşî, Şihâbüddîn Muhammed b. Abdillâh. Tenvîru'l-ebsâr ve câmiu'l-bihâr. thk. Abdülmün'im Halil ỉbrahim. b.y.: Dâru'l-Kütübi'I-IIlmiyye, 1423/2002.

Tirmizî, Ebû İsâ Muhammed b. İsâ. Sünenü't-Tirmizî. thk. Ahmed Muhammed Şâkir vd. 5 Cilt. Mısır: Mektebetü ve Matbaatü Mustafa el-Bâbî el-Halebî, 2. Basım, 1395/1975.

Türkiye Cumhuriyeti Anayasası (Kanun No. 2709). Resmî Gazete 17863 (9 Kasım 1982). Erişim 7 Ekim 2021. https://www.mevzuat.gov.tr/MevzuatMetin/1.5.2709.pdf

Ûdeh, Abdülkâdir. et-Teşrîu'I-cinâiyyü'I-İslâmî. 3 Cilt. Beyrut: Dâru'l-Kitâbi'l-Arabî, ts.

Yiğit, Yaşar. "İslâm Ceza Hukukunda Eşitlik İlkesi ve Dokunulmazlık". Kur'ân Mesajı IImî Araştırmalar Dergisi 13, 14, 15 (1999), 195-206.

Yiğit, Yaşar. "İslâm Ceza Hukuku Hükümleri Bağlamında Zimmîler". Diyanet IIlmî Dergi, 57 (2021), 171-204.

Yiğit, Yaşar. "İslâm Hukukunda Suç-Ceza Dengesinin Adaletle Illişkisi”. Diyanet Ilmî Dergi 56 (2020), 67-94.

Zerkâ, Ahmed b. Muhammed. Şerhu'l-kavâidi'l-fıkhiyye. Dımaşk: Dâru'l-Kalem, 8. Basım, $1430 / 2009$.

Zeydân, Abdülkerim. el-Medhal li dirâseti'ş-şerîati'I-Islâmiyye. Beyrut: Müessesetü'r-Risâle Nâşirûn, 1431/2010.

Zeyla'î, Osman b. Ali Fahruddîn. Tebyînü'l-hakâik şerhu Kenzi'd-dekâik. 6 Cilt. Bulak: elMatbaatü'l-Kübrâ el-Emîriyye, 1313/1895.

Zühaylî, Vehbe b. Mustafa. el-Fıkhu'I-Islâmî ve edilletühû. 10 Cilt. Dımaşk: Dâru'I-Fikr, ts. 